\title{
Nitrogen inputs to a river course in a heavily impacted watershed: a combined hydrochemical and isotopic evaluation (Oglio River Basin, N Italy)
}

Delconte C.A. ${ }^{1,2}$, Sacchi E. ${ }^{2,1}$, Racchetti E. ${ }^{3}$, Bartoli M. ${ }^{3}$, Mas-Pla J. ${ }^{4}$, Re V. ${ }^{5}$

1 - Institute of Geosciences and Earth Resources (IGG), CNR, U.O.S. Pavia, via Ferrata 1, 27100

Pavia, Italy, tel +390382985881, fax +390382985890, e-mail carloandrea.delconte01@ateneopv.it

2 - Department of Earth and Environmental Sciences, University of Pavia, via Ferrata 1, 27100 Pavia, Italy

3 - Department of Life Sciences, University of Parma, viale G.P. Usberti 33/A, 43124 Parma, Italy

4 - Department of Environmental Sciences, University of Girona, Campus de Montilivi, 17071 Girona, and Catalan Institute for Water Research, 17003 Girona, Spain

5 - Department of Molecular Sciences and Nanosystems, University Ca' Foscari of Venice, Dorsoduro 2137, 30123 Venezia, Italy

\section{ABSTRACT:}

This study aims at evaluating sources and processes affecting nitrate concentrations in the Oglio River. Five sampling campaigns considered the main watercourse, tributaries, point pollution sources, springs, and groundwater. Physico-chemical parameters, $\mathrm{N}$ forms, $\mathrm{B}, \mathrm{Sr}$, stable isotopes $\left(\delta^{2} \mathrm{H}_{\mathrm{H} 2 \mathrm{O}}, \delta^{18} \mathrm{O}_{\mathrm{H} 2 \mathrm{O}}, \delta^{15} \mathrm{~N}_{\mathrm{NO} 3}, \delta^{18} \mathrm{O}_{\mathrm{NO} 3}, \delta^{11} \mathrm{~B}\right)$ and discharge were measured. Hydrological modelling was performed using mass balance and End Member Mixing Analysis equations.

During the irrigation period, in the upstream reach, up to $90 \%$ of the natural river flow is diverted for irrigation and industrial purposes; excess water drained from agricultural fields is returned to river in the downstream reach.

Results evidenced, in the middle reach, a large input of nitrate-rich groundwater which could be quantified using hydrological modelling. Groundwater inputs are responsible for the sharp, tenfold increase in nitrates in the river water, from $2.2-4.4$ up to $33.7 \mathrm{mg} \mathrm{L}^{-1}$, and are more evident in summer, when discharge is lower. Nevertheless, river water preserves its natural boron isotopic composition, indicating that the two tracers do not have a common origin and are not co-migrant.

In the lower plain, surface-groundwater interconnections and human disturbances in the water cycle favour the recycling of the compounds in the environment, and lead to the formation of similar chemical pools among the water compartments. The long lasting agronomical practices have profoundly modified the surface-groundwater equilibrium and chemical characteristics, resulting in a highly buffered system. Infiltrating irrigation water leaches down nitrates which are subsequently denitrified; when returned to the river, groundwater modifies its composition by dilution, in the case of nitrates, or by addition, for other constituents.

The results of this study have relevant implications for the management of nitrate pollution in this watershed, suggesting that, in order to reduce the nitrate transport towards the Adriatic Sea, groundwater contamination should be addressed first, with expected long recovery times.

Keywords: nitrate contamination, surface-groundwater interaction, stable isotopes, hydrological modelling, Po Plain 


\section{INTRODUCTION}

The large excess of reactive nitrogen in aquatic bodies is increasingly documented worldwide (Smith, 2003; Galloway et al., 2008) and brings to a number of negative impacts on ecosystems, from eutrophication to anoxia, with relevant potential implications for human health (Smith et al., 1999; Ward et al., 2005; Van Grinsven et al., 2006; Vitousek et al., 1997). Reactive nitrogen originates from multiple sources, including partially treated or untreated sewage, and leaching or runoff from agricultural areas (Erisman et al., 2011). Its way to surface or subsurface aquatic bodies is facilitated by the absence of landscape elements such as riparian buffer strips, by the disappearance of wetlands, by the industrial exploitation of areas unsuitable for agriculture such as gravel soils and by irrigation practices based on flooding with large water volumes (Kato et al., 2009; Durand et al., 2011; Racchetti et al., 2011; Perego et al., 2012). Agricultural and industrial activities, together with civil water use, also heavily alter the hydrological cycle: increasing water volumes are annually abstracted from surface and ground waters, modifying natural flows, retention times, water table fluctuations and groundwater recharge (Dynesius and Nilsson, 1994; Rosenberg et al., 1997; Vörösmarty and Sahagian, 2000).

Recent literature reports numerous studies on nitrogen dynamics at the catchment scale (Rock and Mayer, 2006; Wollheim et al., 2008) and investigations on nitrate origin in surface water courses (Neal et al., 2006, 2008; Ribbe et al., 2008; Lassaletta et al., 2009). Generally, great attention is paid to surface-groundwater interaction (Pittman et al., 1997; Jones and Mulholland, 2000; Reichard and Brown, 2009; Ouyang, 2012) and to the processes of assimilation and biological removal (Neal et al., 2008; Alexander et al., 2009). Studies are mainly based on the combined interpretation of chemical data with statistical techniques, GIS and mathematical models. Recently, the importance of including also isotope geochemistry in environmental studies (Clark and Fritz, 1997; Kendall and McDonnell, 1998; Michener and Lajtha, 2007) has been widely recognised, as reported in different reviews (Nestler et al., 2011; Xue et al., 2009; Fenech et al., 2012). 
Stable isotopes of dissolved nitrates provide a tool enabling to distinguish between nitrates of different origin, to recognize and quantify denitrification in lentic and lotic aquatic environments, and to discuss the $\mathrm{N}$ budget in the soil-water system (Clark and Fritz, 1997; Böhlke et al., 2004; Kendall et al., 2007; Mulholland et al., 2004; Mullholand et al., 2008).

The comparison between $\delta^{15} \mathrm{~N}_{\mathrm{NO} 3}$ and $\delta^{18} \mathrm{O}_{\mathrm{NO} 3}$ values allows the discrimination between $\mathrm{N}$ sources and main biological processes (i.e. nitrification, denitrification and assimilation) affecting nitrate concentration (Mayer et al., 2002; Voss et al., 2006; Lee et al., 2008; Deutsch et al., 2009). Stable isotopes, combined with $\mathrm{NO}_{3}{ }^{-}$analyses, allowed to distinguish between benthic denitrification and denitrification processes occurring in riparian or hyporheic zones of an artificial basin (Der Lake, France) and in the entire hydrographic network of the Seine basin (Sebilo et al., 2003). Mass balances of nitrate isotopes allowed to attribute to phytoplankton assimilation the main decrease of nitrate concentration in a $\sim 600 \mathrm{~km}$ long reach of the Elbe River, as also indicated by the increase of chlorophyll a, while bacterial denitrification was comparatively less important (Deutsch et al., 2009). Mayer et al. (2002) reported low nitrate concentrations in surface waters of forested north American basins and identified by means of isotopic techniques soil nitrification as the main nitrate source. They also evidenced an increase of $\delta^{15} \mathrm{~N}_{\mathrm{NO} 3}$ associated to anthropogenic organic matter (civil waste and manure) in basins with increased urbanization and agricultural activities. Lee et al. (2008) reported similar results for the Han River, with strong correlation between dominant land use and isotopic signals of $\delta^{15} \mathrm{~N}_{\mathrm{NO} 3}$. Nevertheless, the coupled analysis of $\delta^{15} \mathrm{~N}_{\mathrm{NO} 3}$ and $\delta^{18} \mathrm{O}_{\mathrm{NO}}$ does not allow to distinguish manure derived from wastewater derived nitrates (Kendall et al., 2007). To encompass this difficulty, other chemical or isotopic tracers were investigated (e.g. Otero et al. 2009; Fenech et al., 2012; Cary et al., in press; Saccon et al., in press), among which boron $\left(\delta^{11} \mathrm{~B}\right)$ is the most promising (Widory et al., 2005; 2013).

In an agricultural basin of Flanders, the combined analysis of boron and nitrate isotopes assessed the contribution of domestic sewage and greenhouse effluents to the observed nitrate contamination 
(Accoe et al., 2008), while in the Dommel river basin, the combined use of $\delta^{11} \mathrm{~B},{ }^{87} \mathrm{Sr} /{ }^{86} \mathrm{Sr}$ and gadolinium permitted to distinguish the various sources of anthropogenic contamination (PeteletGiraud et al., 2009).

Several studies focused on small basins (Deutsch et al., 2006a, b; Burns et al., 2009; Petitta et al., 2009; Di Lorenzo et al., 2012). These are generally characterized by one dominant land use type (e.g. forest, agricultural, urban), hence nitrate origins and processes affecting concentrations are more easily identified than in larger basins, where multiple contamination sources may coexist (Burns et al., 2009).

Furthermore, the application of mixing models is another effective tool for determining nitrate origin (Deutsch et al., 2006b; Accoe et al., 2008). The use of nitrate isotopes in a mixing model with three different end-members (i.e. drainage water, groundwater and atmospheric deposition) allowed for the quantification of the relative contributions of the three sources to nitrate in a river situated in a small agricultural basin. The obtained percentages were also consistent with the results obtained applying a model for the estimation of nutrient flows in surface watercourses (Deutsch et al., 2006b).

In summary, the combined hydrochemical, hydrogeological, isotopic and modellistic approaches has proven useful in identifying sources and processes affecting nitrate concentrations in small river basins, where well constrained situations are present, or in large river basins, where a dominant land use is present. Very few studies addressed large and heavily impacted river basins, where multiple sources of nitrogen are present and where surface-groundwater interactions vary along the water course. In order to deepen the knowledge of $\mathrm{N}$ dynamics in heavily impacted watersheds and altered river courses, an holistic approach combining information from hydrochemical, isotopic and hydrologic data is necessary, but is still missing.

The Oglio River basin is a good example of basin impacted by agricultural and livestock farming and with an elevated density of inhabitants in the Po River plain (Northern Italy). Soana et al. 
(2011) demonstrated for this watershed a large excess of reactive nitrogen, together with a deep alteration of the river course hydrology. Furthermore, the upstream reaches are fed by seasonally variable amount of groundwater, with a pronounced effect on water chemistry in summer due to lower flows and higher recharge.

In this paper we present hydrological, hydrochemical and isotopic results obtained in the lower Oglio River combined together with a mass-balance approach, with the aim to evaluate the sources and processes affecting nitrate concentrations in the river water, and to investigate the role of groundwater as nitrogen sink or source along the water body. Based on previous investigations (Racchetti et al., 2011; Soana et al., 2011; Bartoli et al., 2012; Sacchi et al., in press), we hypothesized that i) manure and synthetic fertilizers are the dominant $\mathrm{N}$ sources in this agricultural basin, ii) the upstream river portion, flowing on a gravel-rich substratum, accumulates nitrates due to large river-(polluted) groundwater interactions and iii) the downstream river portion, flowing on fine, organic rich sediments, is a $\mathrm{N}$ sink.

The understanding of nitrate sources and sinks in impacted European river basins is also implicitly required by the Nitrates Directive (Directive 91/676/EEC) and Water Framework Directive (Directive 2000/60/EC). The improvement of the water quality in the European countries is a goal to be achieved by 2015 and nutrient monitoring is a mandatory tool to define the water quality status. Nevertheless, in several impacted watersheds, the limitations imposed by the EC Directives to the use of fertilizers in agriculture (especially manure) do not seem to be very effective in preventing or attenuating contamination (EEA, 2010), indicating the need for an unambiguous identification of the $\mathrm{N}$ sources and cycling. 


\section{STUDY AREA}

The lower Oglio River (from here onwards Oglio River) originates from the subalpine Iseo Lake, and flows for about $156 \mathrm{~km}$ before entering the Po River (Fig. 1a). Its watershed lays in the central part of the Po plain (northern Italy), covering an area of $\sim 3,840 \mathrm{~km}^{2}$.

Intensive agriculture, industries and human settlements make the Po River watershed a key, strategic area for the Italian economy, while generated and transported $\mathrm{N}$ loads have a recognised impact on the Mediterranean ecosystem (Franco and Michelato, 1992; Zoppini et al., 1995; Cinnirella et al., 2005). In this context, the Oglio River basin is representative of the most impacted central areas of the Po plain, with nitrate pollution arising from multiple sources, often cumulative. Soana et al. (2011) reported that arable land represents about $60 \%$ of the Oglio River watershed and maize is the dominant crop, covering about $65 \%$ of the arable surface; urbanized land occupies about $12 \%$ of the watershed area $\left(\sim 450 \mathrm{~km}^{2}\right)$. The water cycle of Oglio River is altered by six hydroelectric power plants that temporarily subtract relevant water volumes from the main course, and by a large number of artificial diversions feeding an extensive network of irrigation canals, developed some 500 years ago. During the irrigation period (from late April to early September) large water volumes, up to $90 \%$ of the natural river flow, are diverted for watering and other industrial purposes. Most water abstraction structures are located in the upstream reach (from $\mathrm{km} 0$ to $\mathrm{km}$ 42), while excess water drained from agricultural fields is returned to the Oglio River, mostly after $\mathrm{km} 66$.

The water balance of the Oglio River results from these components:

1. Water flowing out of the Iseo Lake from the Sarnico dam. This amount is strictly regulated to maintain a steady water level in the Lake, and retain water during non-irrigation periods in order to release more water for agricultural needs during summer. Water release from 
Iseo Lake is $45 \pm 33 \mathrm{~m}^{3} \mathrm{~s}^{-1}$ during the non-irrigation period, and $67 \pm 32 \mathrm{~m}^{3} \mathrm{~s}^{-1}$ during the irrigation period (Oglio Consortium data, available at www.laghi.net/Oglio/).

2. The main natural tributaries, namely the Cherio River (confluence at km 15), the Strone

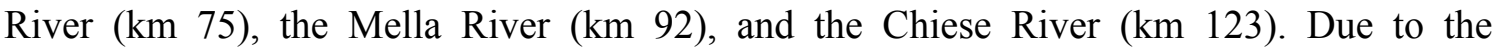
geodynamic evolution of the Po valley, the main tributaries enter the Oglio River in the downstream reach (Fig. 1b).

3. A series of small tributaries and artificial drainage channels. Among these, the more quantitatively relevant are the Roggia Saverona at km 66, Dugale Aspice at km 95, Seriola Gambara at km 104, Naviglio di Isorella at km 116, Scolo Cavata at km 132 and Canale Acque Alte at km 142. During the crop growing season, in summer, they can reach up to 10 $\mathrm{m}^{3} \mathrm{~s}^{-1}$ of discharge each.

4. Groundwater. According to Lombardy Region (2006), the Oglio River is draining variable amounts of groundwater for most of its length. As a reference, the Oglio Consortium, managing the water release from the Sarnico dam, considers a groundwater input to the Oglio River, from late spring to the beginning of autumn, of about $0.5 \mathrm{~m}^{3} \mathrm{~s}^{-1} \mathrm{~km}^{-1}$ between $\mathrm{km} 30$ and $\mathrm{km} 40$.

5. Direct precipitation. The climate is classified as temperate continental (mean annual temperature about $13^{\circ} \mathrm{C}$, mean precipitation about $800 \mathrm{~mm}$ ), with cold winters and hot summers, spring and autumn being characterised by the highest precipitation amount.

The Po plain is filled with sediments belonging to the continental depositional system of PlioPleistocenic age (IRSA-CNR, 1981; Carcano and Piccin, 2002), overlying the marine depositional sequence, and derived by erosion of the Alpine and Apennine ranges. The unconfined aquifer is made of coarse gravels and sands, reaching a cumulative thickness of the water bearing layers from 30 to $150 \mathrm{~m}$ at the centre of the Po basin. The grain size decreases with increasing distance from the 
sediment source (i.e. from $\mathrm{N}$ to $\mathrm{S}$ and from $\mathrm{W}$ to $\mathrm{E}$ ). Accordingly, the permeability of the aquifer in the higher plain greatly exceeds that of the lower plain. The recharge area is located in the Alpine foothills, but the unconfined aquifer is also recharged by direct infiltration of precipitation and irrigation water all over the plain area. Groundwater flow is directed towards the Po River (i.e. roughly oriented N-S in the pre-alpine sector) and is strongly controlled by draining action of the Po River and its tributaries, including the Oglio River (Lombardy Region, 2006). The transition between the higher and the lower plain is marked by numerous permanent outflows, the so-called "springs belt", that runs parallel to the Alps, approximately $30 \mathrm{~km}$ south (Fig. 1b). The outflows in this area originate from the presence of buried structures of the Apennine front, constituting a barrier to the natural groundwater flow towards the Po River (Burrato et al., 2003), or simply from a difference in the aquifer permeability (Pellegrini and Vercesi, 2005). In particular, the sudden change from a N-S to a NW-SE direction of the Oglio River course at about $\mathrm{km} 48$, is related to the presence of a buried Apennine thrust fault (Burrato et al., 2003).

Recently, Sacchi et al. (in press) investigated the origin and fate of nitrates in groundwater from the Lombardy plain. The contamination is unevenly distributed: concentrations $>50 \mathrm{mg} \mathrm{L}^{-1}$ are often observed at the Alpine foothills, while values below $25 \mathrm{mg} \mathrm{L}^{-1}$ characterise the lower plain. In the higher plain, groundwater contamination is favoured by i) the high permeability of the unsaturated zone and of the aquifer; ii) the great depth of the water table; iii) intensive cattle raising and the consequent manure effluents; iv) the large amount of water used for irrigation. Here, stable isotopes of dissolved nitrates indicate the absence of denitrification, while the coupled use of boron isotopes evidences, even in rural areas, a contribution from septic effluents. In the lower plain, denitrification is evidenced both by hydrochemical (Fe, $\mathrm{Mn}$ ) and isotopic tools, and is favoured by a shallow water table, within $5 \mathrm{~m}$ from the surface. 


\section{METHODS}

\subsection{Sampling campaigns and analyses}

Five sampling campaigns were performed in August 2009 (summer), December 2009 (late autumn), February 2010 (winter), July 2010 (summer) and December 2011 in order to evaluate the nitrogen dynamics under different seasonal conditions, namely the non-irrigation and irrigation periods. Each sampling campaign was conducted during several days (Tab. 1). We sampled the main Oglio River water course, for its entire length, its tributaries, at the closing section, outflows of waste water treatment plants (WWTPs) and fish farms (all indicated in figures as point sources), three springs (S1, S2 and S3) discharging in the proximity of the water course, and a well (G1), for a total number of samples ranging between 69 and 80 for each campaign (Fig. 1b and Fig. 2). Flow measurements were also performed by Oglio Consortium, the authority managing water resources in the Oglio River basin, at the same sampling stations. Samples were characterised for $\mathrm{pH}$, $\mathrm{T}$ and conductivity in the field. $\mathrm{N}$ species, sulphate and chloride contents were analysed in the laboratory by means of standard spectrophotometric techniques (APHA, 1981). Dissolved inorganic carbon was measured by $0.1 \mathrm{~N} \mathrm{HCl}$ titration (Anderson et al., 1986).

Several samples from selected campaigns were also analysed for $\mathrm{B}, \mathrm{Sr}$, and stable isotope ratios (Tab. 1). B and $\mathrm{Sr}$ concentrations were determined by ICP-AES. $\delta^{2} \mathrm{H}_{\mathrm{H} 2 \mathrm{O}}\left( \pm 1 \%\right.$ ond $\delta^{18} \mathrm{O}_{\mathrm{H} 2 \mathrm{O}}$ $( \pm 0.2 \%)$ were determined by Wavelength-Scanned Cavity Ring-Down Spectroscopy (WS-CRDS) at ISO4 s.n.c., Italy, with results reported in the usual delta $(\delta)$ notation $v s$ V-SMOW. Nitrate isotopes were determined by IRMS also at ISO4 s.n.c. Samples were prepared and purified according to the method described by Silva et al., 2000. Results are expressed in the delta $(\delta)$ notation $v s$ AIR for $\delta^{15} \mathrm{~N}_{\mathrm{NO} 3}$ and $v s \mathrm{~V}$-SMOW for $\delta^{18} \mathrm{O}_{\mathrm{NO} 3}$, with uncertainties $(1 \sigma)$ of $\pm 0.5 \%$ and $\pm 1 \%$ respectively. Boron isotopes (expressed as $\delta^{11} \mathrm{~B} \%$ ov NBS951) were determined by MC-ICPMS at ALS Scandinavia AB, Sweden, with an uncertainty of \pm 0.4 to $\pm 1 \%$. 


\subsection{Hydrological modelling}

To evaluate the interaction between surface water and groundwater, a general mass-balance approach was used. Calculations were conducted for the Oglio River between sampling stations having a complete set of flow, hydrochemical and isotopic data, belonging to the sampling campaign of July 2010. Samples collected from springs (S1, S2 and S3) and from the well (G1) were considered representative of the chemical and isotopic characteristics of groundwater from the higher and lower plain, respectively. The goal of this numerical modelling exercise is to find out the magnitude and "sign" of the fluxes entering or leaving the Oglio River, as a tool to describe the hydrological dynamics of this system.

The proposed linear mixing model assumes that the stream can be represented by a lumped model, where no other information than the discharge and chemical data at the end-points is available. Diverting/contributing channels and groundwater are also included as general source/sink terms of the stream mass-balance.

The mass balance equation is given by:

$\left\{\begin{array}{c}\mathrm{C}_{2} \mathrm{Q}_{2}=\mathrm{C}_{1} \mathrm{Q}_{1}+\Sigma \mathrm{C}_{\mathrm{SW}} \mathrm{Q}_{\mathrm{SW}}+\Sigma \mathrm{C}_{\mathrm{GW}} \mathrm{Q}_{\mathrm{GW}} \\ \mathrm{Q}_{2}=\mathrm{Q}_{1}+\Sigma \mathrm{Q}_{\mathrm{SW}}+\Sigma \mathrm{Q}_{\mathrm{GW}}\end{array}\right.$

where $\mathrm{C}$ and Q refer to concentration $\left(\mathrm{g} \mathrm{m}^{-3}\right)$ and discharge $\left(\mathrm{m}^{3} \mathrm{~s}^{-1}\right)$, the sub-indexes 1 and 2 refer to the starting and ending points of the stream reach, and the sub-indexes "SW" and "GW" refer to the contribution of tributaries or artificial channels and of groundwater, respectively. The magnitude and the "sign" of both terms, namely $\mathrm{Q}_{\mathrm{sw}}$ and $\mathrm{Q}_{\mathrm{GW}}$, constitute the unknowns of the mass-balance indicated by the solution of the linear mixing model. The first equation indicates a linear mixing 
process, while the second one constrains the discharge of each end-member to be equal to the total discharge after mixing.

Two cases are distinguished:

1. when $\mathrm{Q}_{1}>\mathrm{Q}_{2}$; that is, when a decrease in discharge along the stream reach occurs, we assume water diversion from irrigation or supply channels is larger than water inputs from the aquifer. In this case $\mathrm{C}_{\mathrm{SW}}=\mathrm{C}_{1}$ and the sign of $\mathrm{Q}_{\mathrm{sw}}$ should be negative.

2. when $\mathrm{Q}_{1}<\mathrm{Q}_{2}$; that is, tributaries, channels, and/or water treatment plants contribute to stream discharge with a water input and a dissolved load. This input adds to that of groundwater. In this case, $\mathrm{C}_{\mathrm{SW}}$ is the mean concentration of all the tributaries, and $\mathrm{Q}_{\mathrm{Sw}}$ will represent the sum of all their discharges. Using $\mathrm{C}_{\mathrm{SW}}$ as the mean, we assume that unknown input concentrations will not differ from this averaged value.

Such a simple system of linear equations can be solved by direct substitution of the terms, resulting in:

$\mathrm{Q}_{\mathrm{SW}}=\frac{\mathrm{Q}_{2}\left(\mathrm{C}_{2}-\mathrm{C}_{\mathrm{GW}}\right)+\mathrm{Q}_{1}\left(\mathrm{C}_{\mathrm{GW}}-\mathrm{C}_{1}\right)}{\left(\mathrm{C}_{\mathrm{SW}}-\mathrm{C}_{\mathrm{GW}}\right)}$

$Q_{\mathrm{GW}}=\mathrm{Q}_{2}-\mathrm{Q}_{1}-\mathrm{Q}_{\mathrm{SW}}$

Both equations are solved for conservative tracers, such as chlorides, sulphates, EC, $\mathrm{B}, \mathrm{Sr}$ and $\delta^{18} \mathrm{O}_{\mathrm{H} 2 \mathrm{O}}$ and $\delta^{2} \mathrm{H}_{\mathrm{H} 2 \mathrm{O}}$ values.

An overdetermined system can also be presented using all these variables, or components, and including the discharge relationship condition. This type of modelling is generally referred to as End Member Mixing Analysis [EMMA] (Christophersen et al., 1990; Hooper et al., 1990; Weltje, 1997). As before, the mass-balance expressed by EMMA is given by a linear combination of the contribution of each end-member according to a proportional factor, in our case the inputs from 
surface sources or ground water, or input/outputs from the channels. Equation (1) represents the analysis for a single component. Nevertheless, for several end-members $(\mathrm{n}>1)$, different components $(\mathrm{m})$ can be used to build up a system of equations that considers a linear combination of all components according to the flow contribution from each end-members, generating an overdetermined system of equations. Using matrix notation:

$A x=C$

where $\boldsymbol{A}$ is the matrix $(\mathrm{m}+1, \mathrm{n})$ that contains the concentrations of the different components $(\mathrm{m})$ at each one of the end-member $(n), x$ is the unknown vector $(n, 1)$ that describes the contribution of each end-member to the mixing, and $\boldsymbol{C}$ is the vector $(\mathrm{m}+1,1)$ with the concentrations of each component in the sample. The system also includes the condition that the sum of all contributions must be equal to discharge at the ending point of the stream reach.

The multiple linear regression solution of such overdetermined system is given by:

$x=\left(A^{T} A\right)^{-1} A^{T} C$

where, in our case, $\boldsymbol{x}(2,1)$ contains the unknowns $\mathrm{Q}_{\mathrm{Sw}}$ and $\mathrm{Q}_{\mathrm{GW}}, \boldsymbol{A}$ is the tensor $(2, \mathrm{~m}+1)$ of the $\mathrm{C}_{\mathrm{SW}}$ and $\mathrm{C}_{\mathrm{GW}}$ values for each of the $\mathrm{m}$ components, and $\boldsymbol{C}(\mathrm{m}+1,1)$ is a vector that contains the known terms; i.e., $\mathrm{C}_{2} \mathrm{Q}_{2}-\mathrm{C}_{1} \mathrm{Q}_{1}$ for each component equation. 


\section{RESULTS}

\subsection{Hydrological data}

Water flow in the Oglio River showed marked seasonal differences, with higher discharge in winter compared to summer (Fig 2a). Steep fluctuations of flows are a role in the first $25 \mathrm{~km}$, as a consequence of 6 consecutive hydroelectric power plants and of the presence of water diversion channels; thereafter, tributaries cause a progressive, step like flow increase down to the closing section. During the crop growing season, water flow in the Oglio River displayed a minimum around $\mathrm{km} \mathrm{30,} \mathrm{immediately} \mathrm{downstream} \mathrm{the} \mathrm{last} \mathrm{water} \mathrm{diversion} \mathrm{structure.} \mathrm{More} \mathrm{than} \mathrm{two} \mathrm{thirds} \mathrm{of}$ the arable land is watered by border irrigation, a traditional practice made possible by both abundant water availability in this area and by coarse-textured soils. After $\mathrm{km} \mathrm{40,} \mathrm{a} \mathrm{step-like} \mathrm{increase} \mathrm{in}$ discharge was observed with remarkable seasonal differences. Winter discharge at the river closing section was around 120-180 $\mathrm{m}^{3} \mathrm{~s}^{-1}$ and more than doubled summer values, ranging around 40-60 $\mathrm{m}^{3}$ $\mathrm{s}^{-1}$.

\subsection{Hydrochemical data}

Nitrate concentrations exhibited wide variations along the river course, from a few up to $\sim 40 \mathrm{mg} \mathrm{L}^{-}$

${ }^{1}$; as for water flow there were marked seasonal differences among upstream-downstream patterns (Fig 2b). In the upstream reach (down to $\mathrm{km} \mathrm{20)} \mathrm{the} \mathrm{nitrate} \mathrm{concentrations} \mathrm{reflected} \mathrm{those} \mathrm{of} \mathrm{the}$ Iseo Lake and were rather constant, with values below 4.4 and $2.2 \mathrm{mg} \mathrm{L}^{-1}$ in the winter and in the summer, respectively. In the middle reach ( $\mathrm{km} 20$ to about $\mathrm{km} 80)$, nitrate concentrations increased in all samplings, with significantly steeper increase (from 2.7 to $33.7 \mathrm{mg} \mathrm{L}^{-1}$ ) measured in summer, down to $\mathrm{km} 50$. Such changes were coupled to similar increases in water conductivity and dissolved inorganic carbon concentrations, and to a decrease in water temperature (Tab. 2). In the downstream 
reach of the Oglio, till the closing section, nitrate concentrations tended to remain stable (December 2009 and February 2010) or to decrease (August 2009 and July 2010).

Therefore, based on the patterns of nitrate concentrations, we divided the Oglio River in three main reaches with slightly different lengths among sampling periods. In the graphs, samples pertaining to such reaches are identified through different colour of symbols (Fig. 1b, 2b and followings).

Nitrate concentrations in water samples collected from springs were generally higher than those measured in the Oglio River, and ranged between 30 and $50 \mathrm{mg} \mathrm{L}^{-1}$. Nitrate concentrations measured in natural tributaries, artificial channels, WWTPs and other point sources showed more variability (Fig. 2c) and ranged between 10 to $50 \mathrm{mg} \mathrm{L}^{-1}$.

Concentrations of $\mathrm{Cl}$ and $\mathrm{B}$ (Fig. 3a) in the Oglio River water showed similar patterns, increasing downstream. Chloride concentrations varied by a factor of $\sim 8$, from 2.8 to about $22 \mathrm{mg} \mathrm{L}^{-1}$ and reached highest values in July 2010. Boron concentrations were generally low and ranged between 0.004 and $0.034 \mathrm{mg} \mathrm{L}^{-1}$. Sulphate and strontium concentrations showed different seasonal trends, with higher values measured in summer samplings in the middle reach.

In spring waters (Fig. 3b), sulphates ranged from 44 to $49 \mathrm{mg} \mathrm{L}^{-1}$ and chloride from 6.7 to $12.6 \mathrm{mg}$ $\mathrm{L}^{-1}$. The boron concentration was rather constant, but generally higher in $\mathrm{S} 1\left(0.025-0.029 \mathrm{mg} \mathrm{L}^{-1}\right)$ than in S2 and S3; the lowest value $\left(0.015 \mathrm{mg} \mathrm{L}^{-1}\right)$ was detected at S3 in December 2011. Water collected from springs had the highest strontium concentrations (nearly $0.8 \mathrm{mg} \mathrm{L}^{-1}$ ) in July 2010 and December 2011. In natural and artificial tributaries, the concentrations of analysed chemical species were in the same range of those measured in the Oglio River, while WWTPs may be distinguished because of their relatively high chloride and B contents (Fig. 3b).

\subsection{Isotopic data}

In the Oglio River, the isotopic composition of the water molecule ranged from - 9.32 to $-7.74 \%$ o 
and from -66.3 to $-54.1 \%$ for $\delta^{18} \mathrm{O}_{\mathrm{H} 2 \mathrm{O}}$ and $\delta^{2} \mathrm{H}_{\mathrm{H} 2 \mathrm{O}}$, respectively (Fig. 4). An overall enrichment of the isotopic composition was observed downstream. The results for spring waters were very similar, around $-8.6 \%$ in $\delta^{18} \mathrm{O}_{\mathrm{H} 2 \mathrm{O}}$ and $-60 \%$ in $\delta^{2} \mathrm{H}_{\mathrm{H} 2 \mathrm{O}}$. Data are aligned or fall slightly below the Global Meteoric Water Line (GMWL; Rozanski et al., 1993), with the exception of G1, plotting slightly above.

The isotopic composition of nitrate showed an overall enrichment in $\delta^{15} \mathrm{~N}_{\mathrm{NO} 3}$ from the upstream to the downstream reach of the Oglio River, whereas $\delta^{18} \mathrm{O}_{\mathrm{NO} 3}$ values showed an initial decrease, then increased again in the downstream reach (Fig. 5). Isotopic data generally fell outside the compositional fields defined in the literature for different nitrate sources (Clark and Fritz, 1997; Kendall, 1998), and did not align on a slope typical for denitrification trends. A similar situation was observed for tributaries and springs (Fig. 6), whereas WWTPs outflows showed seasonally varying and more or less pronounced signs of denitrification. Most of the sampled tributaries enter the Oglio River in the downstream reach (black symbols). Compared to the Oglio River water, the nitrate isotopic composition of tributaries was enriched in December 2009, and similar in July 2010. Boron isotopes ranged from -3.8 to $+15.0 \% \delta^{11} \mathrm{~B}$ (Tab. 2). Samples from the Oglio River ranged from +4.9 to $+10.6 \%$; the spring water sample showed a remarkably constant isotopic composition, around $+14 \%$; tributaries were more variable and ranged from -3.2 to $+15.0 \%$; WWTPs showed negative $\delta^{11} \mathrm{~B}$ (Sacchi et al., in press), in agreement with literature data (Seiler, 2005; Widory et al., 2005; Tirez et al., 2010).

\subsection{Results of the hydrological modelling}

The results of the mass balance calculations (equations $2 \mathrm{a}$ and $2 \mathrm{~b}$ ) coupled to the solution of the multiple linear regression system (equation 4) for the first $46 \mathrm{~km}$ of the Oglio River length, using the July 2010 survey data, are reported in Tab. 3. In this reach, during this survey, the Oglio River 
discharge decreases and minimum values are achieved (Fig. 2a). Such a decrease is due to water diversion in artificial channels for irrigation purposes $\left(Q_{s w}\right.$ in Tab. 3, corresponding to $-22.32 \pm 0.52$, $-16.12 \pm 0.47$, and $-3.93 \pm 0.75 \mathrm{~m}^{3} \mathrm{~s}^{-1}$, for the reaches between $\mathrm{km} \mathrm{15-26,26-36}$ and 36-46, respectively), yet compensated by groundwater inputs to the river $\left(\mathrm{Q}_{\mathrm{GW}}\right.$ In Tab. 3, corresponding to $3.80 \pm 0.52,4.18 \pm 0.47$, and $5.89 \pm 0.75 \mathrm{~m}^{3} \mathrm{~s}^{-1}$ for the same reaches). Notably, while the amount of water abstracted changes with distance, due to distinct irrigation channels, the groundwater input to the river shows a similar magnitude with a slight increase downstream.

However, EC, chloride, sulphate, and Sr contents were only considered for the linear system solution on the reach $36-46 \mathrm{~km}$. Indeed for the water isotopes, the mass balance returns an opposite sign for $\mathrm{Q}_{\mathrm{GW}}$ and $\mathrm{Q}_{\mathrm{SW}}$ if $\delta^{18} \mathrm{O}_{\mathrm{H} 2 \mathrm{O}}$ rather than $\delta^{2} \mathrm{H}_{\mathrm{H} 2 \mathrm{O}}$ values are used in the calculation, whereas for $\mathrm{B}$ a positive result both for $\mathrm{Q}_{\mathrm{GW}}$ and $\mathrm{Q}_{\mathrm{SW}}$ is obtained. Moreover, a little increase in discharge is observed, as a result of larger groundwater contribution than channel diversion, since no tributaries contributing to the Po River occur in this reach. Also, in the three reaches constituting the upstream and part of the middle reach of the Oglio River, EMMA calculations, using data reported in Tab. 3 , provide magnitudes for the amount of water diverted to irrigation and for groundwater input to the Oglio similar to those obtained using a mass-balance based on individual variables.

From $\mathrm{km} 46$ to $\mathrm{km} \mathrm{59,} \mathrm{the} \mathrm{hydrological} \mathrm{modelling} \mathrm{could} \mathrm{not} \mathrm{be} \mathrm{performed} \mathrm{because} \mathrm{of} \mathrm{the} \mathrm{presence}$ of an important tributary, causing a detectable increase in discharge, which could not be sampled. From $\mathrm{km} 59$ to the Po River confluence, the application of the linear model takes into account the chemical and isotopic composition of tributaries. In this case, chemical variables of tributary flows contributing to the Oglio River discharge are represented by a mean value of all tributaries. However, tributary and groundwater input rates are actually distinct for each variable. In particular, results differ in magnitude and/or in sign for surface and groundwater contributions, evidencing strong discrepancies between the different variables. Nevertheless, the EMMA approach based on the use of many variables to estimate tributaries and groundwater fluxes provide an average surface 
input of $48.2 \mathrm{~m}^{3} \mathrm{~s}^{-1}$. In this reach, an average loosing stream $\left(-2.72 \mathrm{~m}^{3} \mathrm{~s}^{-1}\right)$ behaviour seems to occur along the almost $100 \mathrm{~km}$ of the downstream reach length. This contrasts with the gaining stream scenario that dominates the upper and middle reaches of the Oglio River (km 15 to 46).

\section{DISCUSSION}

As many rivers within heavily exploited watersheds, the Oglio River is characterized by altered hydrology, with an irrigation dependent flow regulation at its origin, a number of diversion structures in the upstream sections and a series of discontinuities associated to adjacent hydroelectric power plants. As a result, rather defined hydrological and hydrochemical features (with nitrate data as key parameter) allow to divide the river in three reaches (upstream, middle and downstream).

Summer samplings were particularly useful in order to highlight the nitrogen input to this river, as flow in the river course was reduced by water abstraction for agriculture, resulting in lower dilution capacity and marked variations of nitrate concentrations. This was evident in the middle reach, downstream the last irrigation channel and where river-groundwater interaction peaks. Our data and calculations suggest a marked decrease of flow, mostly due to water abstraction, which is only partially compensated by the ingression of nitrate-rich groundwater. Surface and groundwater interaction in the middle reach of the Oglio river and its effects on water quantity and quality are one of the main outcomes of the present study. They stress the relevance of deepening the knowledge of nitrogen dynamics in aquifers, in terms of dominant processes, timing of transfer of this pollutant and hydraulic modelling of the hyporheic zone (Sophocleous, 2002).

In the watershed portion associated to the downstream river reach, water used to irrigate agricultural lands is drained by the secondary channel network and by runoff, and is subsequently returned to 
the main course. Here, the number of co-occurring processes and of nitrogen sources that add to the overall picture (civil and industrial, beside agricultural), are elevated due to the high population and infrastructure density. The greatly altered hydrology and the multiple $\mathrm{N}$ sources and processes alter the water chemical and isotopic characteristics. With this respect, evidences of such complex mixing are provided by hydrochemical and isotopic data and by the difficult interpretation of the results of hydrological modeling.

\subsection{Upstream and middle reaches}

In the upstream reach the concentrations of dissolved solutes, and particularly those of inorganic nitrogen, do not display significant patterns, reflecting the chemistry of the Iseo Lake and the absence of significant inputs of contaminants (in terms of incoming loads, i.e. the combination of flows and concentrations). For example, the contribution of WWTP, characterised by B rich water but low discharge, is not recorded by the river water chemical and isotopic composition.

In the middle reach, on the contrary, a consistent pattern among all sampling periods was observed, with a general increase of dissolved constituents (Fig. $2 \mathrm{~b}$ and $3 \mathrm{a}$ ). Our data suggest that such a significant alteration of the Oglio River water chemistry cannot be attributed to surface water contributions or point source pollution, as neither significant tributaries nor WWTPs outflows are present in this reach. Neither the concentration trend shown by nitrates can be explained by microbial processes such as nitrification in the water column, as the concentrations of reduced nitrogen forms (ammonium, dissolved and particulate organic N) are low (Bartoli et al., 2012). The middle reach geographically encompasses the "springs belt" area (Fig. 1b), which represents the natural discharge area of the unconfined aquifer located in the higher plain (Sacchi et al., in press). Spring water samples collected close to the river course exhibit a markedly different chemical composition compared to the Oglio River water, with higher and rather constant content of dissolved salts, and in particular of nitrates (Tab.2 and Fig. 2c). The chemistry of spring waters 
displays a narrow seasonal variability, limited to the irrigation period, where agricultural return flow contributes to spring discharge (Laini et al., 2011). Nitrate concentrations are comparable with those measured in other springs of the Oglio River watershed (Laini et al. 2011) and in groundwater from the higher plain (Sacchi et al, in press). For this reason we can reasonably assume that the composition of spring water is representative of the composition of groundwater from the unconfined aquifer of the higher plain. We argue that, in the "spring belt" area, and in particular during summer months, limited flows in the river course mix with groundwater, and the Oglio River chemistry approaches that of the springs. Such outcome is supported by nitrate as well as by $\mathrm{Cl}^{-}$, $\mathrm{SO}_{4}{ }^{2-}$, and $\mathrm{Sr}$ concentrations, and is likely a consequence of the partial and progressive replacement of river water abstracted for irrigation with subsurface inputs.

Additional evidence is provided by the isotopic tracers. Stable isotopes of the water molecule (Fig. 4) in the sample from the upstream reach (white triangle) are depleted. The isotopic composition measured at $\mathrm{km} 15\left(\delta^{18} \mathrm{O}_{\mathrm{H} 2 \mathrm{O}}=-9.32 \%\right.$ ) corresponds to a mixture of Alpine and local precipitation (group B water in Pilla et al., 2006; Longinelli and Selmo, 2003). Since this sample (and the following two downstream ones) fall below the GMWL, their composition might also have been enriched by evaporation in the Iseo Lake, before entering the Oglio River. In the middle reach (grey triangles), $\delta^{18} \mathrm{O}_{\mathrm{H} 2 \mathrm{O}}$ approaches the isotopic composition of groundwater, i.e. that displayed by springs $\left(\delta^{18} \mathrm{O}_{\mathrm{H} 2 \mathrm{O}} \approx-8.55 \%\right.$ ). Moreover, the isotopic composition of dissolved nitrates in the upstream reach (white triangles in Fig. 5), where nitrate concentrations are normally below $5 \mathrm{mg} \mathrm{L}^{-}$ 1 , is close to the compositional field of atmospheric sources (i.e. a nitrate contribution form atmospheric deposition or from synthetic fertilisers). Moving downstream, in the middle reach (grey colour in Fig. 5) the nitrate isotopic composition becomes progressively more enriched in $\delta^{15} \mathrm{~N}_{\mathrm{NO}}$ and depleted in $\delta^{18} \mathrm{O}_{\mathrm{NO} 3}$, indicating an increasing contribution from organic sources: in this reach the isotopic signature of nitrate is consistent with that displayed by springs (Fig. 5).

In order to better assess whether the anthropogenic organic matter contribution is from manure or 
from untreated wastewater, B isotopes were investigated. Results are reported in Fig. 7, together with the values for groundwater samples from the Lombardy plain (Sacchi et al., in press). The $\delta^{11} \mathrm{~B}$ of spring waters (around $+14 \%$ ) is comparable with the isotopic composition of groundwater showing the lower concentrations, therefore assumed by Sacchi et al. (in press) as the presumably "uncontaminated" end-member. The isotopic composition of the Oglio River water in the upstream reach shows even lower $\mathrm{B}$ concentrations and is isotopically more depleted. When flowing downstream, despite the increase in B concentration (Fig. 3a) the isotopic composition remains rather constant $(+6.17 \%$ $\pm 0.97 ; \mathrm{n}=9)$. The only exception is the sample collected in summer at $\mathrm{km}$ $59\left(\delta^{11} \mathrm{~B}=10.64 \%\right)$, which approaches the concentration and isotopic composition of springs and groundwater. This similarity in composition is an additional evidence of groundwater mixing with the river water.

The interpretation is validated by the results of the hydrological modelling, assessing a progressively more important contribution of groundwater to the river flow from the upper to the middle reach. In the upper reach water abstraction $\left(-22 \mathrm{~m}^{3} \mathrm{~s}^{-1}\right)$ is only partially compensated by inflows $\left(+5 \mathrm{~m}^{3} \mathrm{~s}^{-1}\right)$ while in the middle reach the abstraction $\left(-3 \mathrm{~m}^{3} \mathrm{~s}^{-1}\right)$ is more than compensated by inflows $\left(+5 \mathrm{~m}^{3} \mathrm{~s}^{-1}\right)$ (Tab. 3). The contribution of groundwater to the river flow is comparable with that estimated by the Oglio Consortium solely based on discharge measurements, of about $0.5 \mathrm{~m}^{3} \mathrm{~s}^{-}$ ${ }^{1} \mathrm{~km}^{-1}$ after $\mathrm{km} \mathrm{30}$. As the chemistry of groundwater is significantly different from that of surface water, the relevant volumetric input from the spring belt to the Oglio River determines a measurable change in the river water quality, with up to a tenfold increase of nitrate concentrations. Ultimately, the mixing of river and groundwater results in river eutrophication.

Studies on nutrient enrichment caused by storm water and runoff are common in the literature while, to our knowledge, only a few authors attempted to quantify the relevance of groundwatersurface water interaction for the chemistry of river waters, as we did (Sophocleous, 2002; Petitta et al., 2009; Ouyang, 2012; Di Lorenzo et al., 2012). Ouyang (2012), for example, estimated with the 
Darcy's law the groundwater recharge to the St. Johns River (Florida), and calculated the N and P loads to the river water at 4 sites. However, contrarily to our study, he did not analyze the overall change in river concentrations downstream the groundwater-surface water mixing zones. Di Lorenzo et al. (2012), with a combined isotopic and chemical approach, analyzed the nitrogen exchange between the aquifer and the river, and could distinguish zones where the Vibrata River (central Italy) is fed by the aquifer and where the river feeds the aquifer. Their measurements and calculations suggest that nitrogen migrates from the river to groundwater, where it is partially denitrified in the hyporeic zone. Petitta et al. (2009), in a similar study, demonstrated that the shallow aquifer represents a significant nitrogen source for the irrigation channels within the Fucino watershed (central Italy) in early spring and autumn.

When considering the relevance of the contamination input, our case study largely exceeds what reported in the literature. Pittman et al. (1997) reported low nitrate concentrations both in the Suwannee River $\left(\mathrm{NO}_{3}{ }^{-}<1 \mathrm{mg} \mathrm{L}^{-1}\right)$ and in spring waters feeding the river; Di Lorenzo et al. (2012) found a nitrate concentration of about $4 \mathrm{mg} \mathrm{L}^{-1}$ in the reach of the Vibrata River (Italy) fed by the aquifer; Deutsch et al. (2006b) in a sub catchment of the Warnow River (Germany) estimated with the application of a mixing model the nitrate contribution from groundwater to $11 \%$ during Winter. By comparison, nitrates in the Oglio River reach up to $33 \mathrm{mg} \mathrm{L}^{-1}$ in summer, and the groundwater input causes a tenfold increase in concentrations. When considering that other pollutants such as pesticides or herbicides are likely present in the unconfined aquifer, and may be exchanged and recycled to the surface, future research should address efforts and develop methods for the quantitative analysis of surface-groundwater interactions (Pacioni et al., 2007; Laini et al., 2012; Ouyang, 2012).

\subsection{Downstream reach}

The nitrate origin and its dynamics are more difficult to assess in the downstream reach of the Oglio 
River. Here, dissolved constituents display different patterns: nitrate, sulphate and Sr concentrations remain constant or slightly decrease, especially in summer, whereas B and, to a lower extent, chloride concentrations always increase.

Denitrification, as a dominant process, should result in net decrease of nitrate in the Oglio River water, a phenomena that was not clearly evident from our $\mathrm{NO}_{3}{ }^{-}$concentration and isotopic data. Nitrate isotopes do not support the relevance of denitrification process in the downstream sector of the Oglio River, as downstream samples (black symbols in Fig. 5) are grouped together, and not clearly aligned along the expected denitrification trend. On the contrary, rather constant or slightly decreasing concentrations suggest low denitrification rates compared to a very large pool transported downstream or equilibrium between multiple $\mathrm{N}$ sources (lateral inputs or within river nitrification) and sinks ( $\mathrm{N}_{2}$ production).

When nitrates tended to decrease in the downstream reach (as in the July 2010 sampling) we speculate that dilution of river water with nitrate-depleted inputs could be responsible. This dilution might be attributed to the inflow of tributaries and/or to an input of groundwater.

Tributaries display nitrate concentrations very similar to those displayed by the river water (Fig. 2c). Their isotopic composition, in some cases, clearly falls in the box identifying the isotopic composition of anthropogenic organic matter (Clark and Fritz, 1997; Kendall, 1998), but most samples from the downstream reach (black symbols) are enriched both in $\delta^{15} \mathrm{~N}_{\mathrm{NO} 3}$ and $\delta^{18} \mathrm{O}_{\mathrm{NO} 3}$. This composition is indicative of residual nitrates enriched by denitrification and/or mixing of multiple sources and/or nitrates which have undergone recycling processes in the environment (Kendall et al., 2007). Groundwater, instead, is mostly deprived of nitrates, as a consequence of intense denitrification phenomena both in soils and in the shallow unconfined aquifer of the lower plain of Lombardy (Sacchi et al., in press). Notably, the isotopic composition of G1, the groundwater sample collected in the lower plain, is highly enriched in isotopic composition (Fig. 5), as in denitrified groundwater. Tributaries show higher B concentrations than river water (Fig.7) and their 
isotopic composition generally deviates towards positive or negative values, indicating a larger contribution of B from manure or domestic sources (WWTP). On the same plot, G1 seems to better fit with both concentration and isotopic composition of river water. Finally, water isotopes (Fig. 4) also remain constant in river water, with a composition $\left(\delta^{18} \mathrm{O}_{\mathrm{H} 2 \mathrm{O}} \approx-8.5 \%\right.$ o comparable to that observed for G1. In this reach, only one sample is enriched up to $\delta^{18} \mathrm{O}_{\mathrm{H} 2 \mathrm{O}}=-7.7 \%$, and plots below the GMWL. This sample could indicate an additional contribution from local precipitation, from tributaries (e.g. Mella River, $\delta^{18} \mathrm{O}_{\mathrm{H} 2 \mathrm{O}}=-7.89 \%$ ), or from agricultural return flow.

A final argument in favour of a dominant input of nitrate-depleted groundwater to the downstream reach of the Oglio River is the remarkably similar $\mathrm{B}$ and $\mathrm{Cl}$ concentrations in river water between summer and winter, if compared to the change in discharge which more than doubles in winter compared to the summer. This would indicate that these ions are provided by a unique source which also sustains the water flow.

Unfortunately, the contribution of tributaries and/or groundwater in the downstream reach cannot be demonstrated and quantified unequivocally using a single variable mass balance approach. Discrepancies in the results provided by the different components (Tab. 3) are due to the similar values for chemical and isotopic variables between successive sampling points since, in the downstream reach, most hydrochemical and isotopic contents remain constant in concentration or are subject to little variations. In addition, also the chemical and isotopic composition of the possible contributions (tributaries and groundwater) are very similar, requiring large inputs or outputs to explain the observed variations. However, the use of EMMA, based on an overdetermined system of equations, provides a rough estimate of the tributaries and groundwater inputs, which is consistent with hydrological observations. 


\section{CONCLUSION}

The multi tracer, multi isotope approach used in our study allowed to evidence, in the upstream and middle reach of the Oglio River, a large input of nitrate-rich groundwater which could be quantified using hydrological modelling based on mass balance and EMMA equations. The input of contaminated groundwater is responsible for the sharp increase in dissolved nitrates in the river water, and is more evident in summer, when discharge is low due to abstraction for irrigation purposes. This is one of the few studies where it was demonstrated that unconfined aquifers are a pollution source to surface waters, altering their water chemistry and quality. Such finding has a number of implications, dealing mainly with the strategies to put in act in order to remove nitrate from the groundwater.

Also, in the downstream reach, river-groundwater interactions likely occur, but the main difference with upstream reaches is that the groundwater is nitrate-depleted, resulting in constant or slightly decreasing nitrate concentrations in the river water. However, the latter speculation could not be rigorously demonstrated and quantified with the hydrological modelling. To disentangle the hydrological complexity of the investigated system, future research should address more in detail the downstream reach of the Oglio River, with an even more intense sampling strategy focussed on shorter segments.

The use of the isotopic triptych $\left(\delta^{15} \mathrm{~N}_{\mathrm{NO} 3}, \delta^{18} \mathrm{O}_{\mathrm{NO} 3}\right.$ and $\left.\delta^{11} \mathrm{~B}\right)$ indicates, for the considered tributaries, an input of anthropogenic organic matter, where the contribution of WWTPs is detectable, especially in the lower plain. Unfortunately, the isotopic approach was not as successful when applied to the Oglio River water. Indeed, while nitrates are proven to derive from the input of contaminated groundwater from the higher plain, the natural B isotopic composition is preserved. This would indicate that, in our case study, the two tracers do not have a common origin and are not 
co-migrant. This decoupling evidences the peculiarity of the two tracers and offers some hints on nitrate dynamics. Indeed in the lower plain, the recycling of the elements and chemical compounds in the environment, due to surface-groundwater interconnections, coupled to human disturbances in the water cycle (i.e. groundwater exploitation, surface water diversion, irrigation practices and discharges), led to the formation of similar chemical pools among the water compartments. In other words, the long lasting agronomical practices of irrigation have profoundly modified the groundwater-surface water equilibrium and chemical characteristics in the lower plain, resulting in a highly buffered system. Irrigation water, while passing through the soil, leaches down nitrates which are subsequently denitrified, whereas boron is retained in the soil by adsorption. When returned to the Oglio River, groundwater modifies the river water composition by dilution, in the case of nitrates, or by addition in the case of other constituents.

The large inertia and buffer capacity of the combined soil-groundwater-surface water system result in an apparent steady state, for both hydrochemical and isotopic composition. We are aware that the equilibrium is only apparent and not real, as processes can be uniform along the river course but flows are not, with a pronounced seasonal variation (depending upon the diversion/irrigation period), that results in profoundly different mixing rates between surface and groundwater. With this respect, this is a prime example of how the long lasting agronomical practices in intensively cultivated areas such as the Po plain have modified the environment, smoothing and homogenizing expected differences.

The results of this study have relevant implications for the management of nitrate pollution in this watershed. Indeed, in order to reduce the nitrate transport to the Po River and ultimately to the Adriatic Sea, as indicated by the EU regulators, groundwater contamination in the higher plain needs to be addressed first. In absence of a nitrate removal by denitrification, the improvement of groundwater quality will be achieved only by the natural replacement in the aquifer with nitrate-free groundwater. Since the turnover time of groundwater is much larger than that of surface water 
bodies, long recovery times are to be expected.

\section{Aknolwdgements}

This research project was co-funded by CNR-IGG and Regione Lombardia, Department of Agriculture. The authors wish to acknowledge Eng. M. Buizza, Director of the Oglio River Consortium, and the Regional Agency for the Environmental Protection of Lombardy (ARPA Lombardia) for data provision. E. Racchetti was supported by the Lombardy Foundation for the Environment (FLA). We also acknowledge the collaboration of M. Pennisi (CNR-IGG) and E. Allais (ISO4 s.n.c). D. Zizioli and D. Notti (University of Pavia) are acknowledged for their invaluable help in the use of GIS software.

\section{REFERENCES}

Accoe F, Berglund M, Duta S, Hennessy C, Taylor P, Van Hoof K, De Smedt S. Source apportionment of nitrate pollution in surface water using stable isotopes of $\mathrm{N}$ and $\mathrm{O}$ in nitrate and B: a case study in Flanders (Belgium). European Commission, Joint Research Centre, Institute for Reference Materials and Measurements, Geel, EUR 23425 EN; 2008.

Alexander RB, Böhlke JK, Boyer EW, David MB, Harvey JW, Mulholland PJ, et al. Dynamic Modeling of nitrogen losses in river networks unravels the coupled effect of hydrological and biogeochemical processes. Biogeochemistry 2009; 93:91-116.

Anderson LG, Hall POJ, Iverfeldt A, Van Der Loeff MMR, Sundby B, Westerlund SFG. Benthic respiration measured by total carbonate production. Limnol Oceanogr 1986; 31:319-329.

APHA, AWWA, WPCF (Eds): Standard methods for the examination of water and wastewater. Am. Publ. Health. Ass., Washington; 1981.

Bartoli M, Racchetti E, Delconte CA, Sacchi E, Soana E, Laini A, et al. Nitrogen bilance and fate in a heavily impacted watershed (Oglio River; Northern Italy): in quest of the missing sources and sinks. Biogeosciences, 2012; 9:361-373.

Böhlke JK, Harvey JW, Voytek MA. Reach-scale isotope tracer experiment to quantify denitrification and related processes in a nitrate-rich stream. Limnol Oceanogr 2004; 49:821838.

Burrato P, Ciucci F, Valensise G. An inventory of river anomalies in the Po Plain, Northern Italy: evidence for active blind thrust faulting. Ann Geophys 2003; 46:865-882. 
Burns DA, Boyer EW, Elliott EM, Kendall C. Sources and transformation of nitrate from stream draining varying land uses: evidence from dual isotope analysis. J Environ Qual 2009; 38:11491159.

Carcano C, Piccin A (Eds.). Geologia degli acquiferi padani della Regione Lombardia [Geology of the Po Plain aquifers in the Lombardy region]. Regione Lombardia and ENI Divisione AGIP, S.E.L.C.A. Firenze (in Italian); 2002.

Cary L, Casanova J, Gaaloul N, Guerrot C. Combining boron isotopes and carbamazepine to trace sewage in salinized groundwater: a case study in Cap Bon, Tunisia. Appl Geochem in press.

Christophersen N, Neal C, Hooper RP, Vogt RD, Andersen S. Modeling stream water chemistry as a mixture of soil water end-members - a step towards second-generation acidification models. J Hydrol 1990; 116:307-320.

Cinnirella S, Buttafuoco G, Pirrone N. Stochastic analysis to assess the spatial distribution of groundwater nitrate concentrations in the Po catchment (Italy). Environ Pollut 2005; 133:569580 .

Clark I, Fritz P. Environmental Isotopes in Hydrogeology. Lewis Publishers, Boca Raton; 1997.

Deutsch B, Kahle P, Voss M. Assessing the source of nitrate pollution in water using stable N and O isotopes. Agron Sustain Dev 2006a; 26:263-267.

Deutsch B, Mewes M, Liskow I, Voss M. Quantification of diffuse nitrate inputs into a small river system using stable isotopes of oxygen and nitrogen in nitrate. Org Geochem 2006b; 37:13331342 .

Deutsch B. Voss M, Fischer H. Nitrogen transformation processes in the Elbe River: Distinguishing between assimilation and denitrification by means of stable isotope ratios in nitrate. Aquat Sci 2009; 71:228-237.

Di Lorenzo T, Brilli M, Del Tosto D, Galassi DMP, Petitta M. Nitrate source and fate at the catchment scale of the Vibrata River and aquifer (central Italy): an analysis by integrating component approaches and nitrogen isotopes. Environ Earth Sci 2012; 67:2383-2398.

Dynesius M, Nilsson C. Fragmentation and flow regulation of river systems in the northern third of the world. Science 1994; 266:753-762.

Directive 91/676/EEC. Council Directive of 12 December 1991 concerning the protection of waters against pollution caused by nitrates from agricultural sources. Off. J. Eur. Commun. L 375, 1-8. Available at: http://eur-

lex.europa.eu/LexUriServ/LexUriServ.do?uri=OJ:L:1991:375:0001:0008:EN:PDF

Directive 2000/60/EC of the European Parliament and of the Council of 23 October 2000 establishing a framework for Community action in the field of water policy, Official Journal of the European Communities, L 327, 1-72. Available at: http://eurlex.europa.eu/LexUriServ/LexUriServ.do?uri=OJ:L:2000:327:0001:0072:EN:PDF

Durand P, Breuer L, Johnes JP, Billen G, Butturini A, Pinay G, van Grinsven H, Garnier J, Rivett M, Reay DS, Curtis C, Siemens J, Maberly S, Kaste Ø, Humborg C, Loeb R, de Klein J, Hejzlar J, Skoulikidis N, Kortelainen P, Lepisthö A, Wright R. Nitrogen processes in aquatic ecosystems (Chapter 7). In : Sutton AM, Howard CM, Erisman JW, Billen G, Bleeker A, Greenfelt P, van Grinsven H, Grizzetti B, editors. The European Nitrogen Assessment: source, effect and policy perspective. Cambridge University Press, New York, 2011; 126-146.

EEA, 2010. The european environment. State and outlook 2010. Freshwater quality. European Environment Agency, Copenhagen. Available at: 


\section{http://eur-lex.europa.eu/LexUriServ/LexUriServ.do?uri=OJ:L:2000:327:0001:0072:EN:PDF}

Franco P, Michelato A. Northern Adriatic Sea: oceanography of the basin proper and of the western coastal zone. In: Vollenweider RA, Marchetti R, Viviani R, editors. Marine Coastal Eutrophication. Sci Total Environ Supp 1992; 35-62.

Erisman WJ, van Grinsven H, Grizzetti B, Bouraoui F, Powlson D, Sutton MA, Bleeker A, Reis S. The European nitrogen problem in a global perspective (Chapter 2) In : Sutton MA, Howard CM, Erisman JW, Billen G, Bleeker A, Greenfelt P, van Grinsven H, Grizzetti B, editors. The European Nitrogen Assessment: source, effect and policy perspective. Cambridge University Press, New York, 2011; 9-31.

Fava L, Orrù MA, Scardala S, Alonzo E, Fardella M, Strumia C, et al. Pesticides and their metabolites in selected Italian groundwater and surface water used for drinking. Ann Ist Super Sanità 2010; 46:309-316.

Fenech C, Rock L, Nolan K, Tobin J, Morrissey A. The potential for a suite of isotope and chemical markers to differentiate sources of nitrate contamination: A review. Water Res 2012; 46:20232041.

Galloway JN, Townsend AR, Erisman JW, Bekunda M, Cai Z, Freney JR, Martinelli LA, Seitzinger SP, Sutton MA: Transformation of the nitrogen cycle: recent trends, questions, and potential solutions. Science 2008; 320:889-892.

Hooper RP, Christophersen N, Peters NE. Modelling streamwater chemistry as a mixture of soilwater end-members - an application to the Panola Mountain catchment, Georgia, U.S.A. J Hydrol 1990; 116: 321-343.

IRSA-CNR. Indagine sulle falde acquifere profonde della Pianura Padana [Investigation on the Po Plain deep aquifers]. Quaderni IRSA 51/2 1981; 1-70 (in Italian).

Jones BJ, Muholland PJ. Streams and Ground Waters. Jones JB, Mulholland PJ, editors. Academic Press, San Diego, California; 2000.

Kato T, Kuroda H, Nakasone $\mathrm{H}$. Runoff characteristics of nutrients from an agricultural watershed with intensive livestock production. J Hydrol 2009; 368:79-87.

Kendall C. Tracing Nitrogen Sources and Cycling in Catchments. In: Kendall C, McDonnell JJ editors. Isotope Tracers in Catchment Hydrology, Elsevier Science B.V., Amsterdam ; 1998. p. 519-576.

Kendall C., McDonnell JJ. Isotope tracers in catchment hydrology. Elsevier Science B.V., Amsterdam 1998.

Kendall C, Elliott EM, Wankel SD. Tracing anthropogenic inputs of nitrogen to ecosystems. In: Michener R, Lajtha K, editors. Stable Isotope in Ecology and Environmental Science. Blackwell Publishing Inc., Oxford UK, 2nd edition , 2007; p. 375-449.

Laini A, Bartoli M, Castaldi S, Viaroli P, Capri E, Trevisan M. Greenhouse gas $\left(\mathrm{CO}_{2}, \mathrm{CH}_{4}\right.$, and $\mathrm{N}_{2} \mathrm{O}$ ) within an agricultural impacted watershed (Po River Plain, Northern Italy). Chem Ecol 2011; 27: 177-187.

Laini A, Bartoli M, Lamastra L, Capri E, Balderacchi M, Trevisan M. Herbicide contamination and dispersion pattern in lowland springs. Sci Total Environ 2012; 438: 312-318.

Lassaletta L, García-Gómez H, Gimeno BS, Rovira JVAgriculture-induced increase in nitrate concentrations in stream waters of a large Mediterranean catchment over 25 years (1981 - 2005). Sci Total Environ 2009; 407:6034-6043. 
Lee KS, Bong YS, Lee D, Kim Y, Kim K. Tracing the sources of nitrate in the Han River watershed in Korea, using $\delta^{15} \mathrm{~N}-\mathrm{NO} 3$ - and $\delta^{18} \mathrm{O}-\mathrm{NO} 3$ - values. Sci Total Environ 2008; 395: 117-124.

Longinelli A, Selmo E. Isotopic composition of precipitation in Italy: a first overall map. J Hydrol 2003; 270: 75-88.

Lombardy Region, 2006. Water Protection Plan. Available at:

http://www.ors.regione.lombardia.it/cm/pagina.jhtml;jsessionid=1627031D6757F363ABE37410 87B6C2AE.node1?param1_1=N11e3afc18be8ce5ad6f

Mayer B, Boyer EW, Goodale C, Jaworski NA, Van Breemen N, Howarth RW, et al. Sources of nitrate in rivers draining sixteen watersheds in the northeastern U.S.: Isotopic constraints. Biogeochemistry 2002; 57/58:171-197.

Michener R, Lajtha K. Stable Isotopes in Ecology and Environmental Science. Blackwell Publishing Inc., Oxford UK, 2nd edition; 2007.

Mulholland PJ, Valett HM, Webster JR, Thomas SA, Cooper LW, Hamilton SK, Peterson BJ. Stream denitrification and total nitrate uptake rates measured using a field ${ }^{15} \mathrm{~N}$ tracer addition approach. Limnol Oceanogr 2004; 49: 809-820.

Mulholland PJ, Helton AM, Poole GC, Hall RO. Jr, Hamilton SK, Peterson BJ, et al. Stream denitrification across biomes and its response to anthropogenic nitrate loading. Nature, Letters 2008; 452: 202-206.

Neal C, Jarvie HP, Neal M, Hill L, Wickham H,. Nitrate concentrations in river waters of the upper Thames and its tributaries. Sci Total Environ 2006; 365:15-32.

Neal C, Jarvie H P, Love A, Neal M, Wickham H., Harman S. Water quality along a river continuum subject to point and diffuse sources. J Hydrol 2008; 350: 154-165.

Nestler A, Berglund M, Accoe F, Duta S, Xue D, Boeckx P, Taylor P. Isotopes for improved management of nitrate pollution in aqueous resources: review of surface water field studies. Environ Sci Pollut R 2011; 18:519-533.

Otero N, Torrentó C, Soler A, Menció A, Mas-Pla J. Monitoring groundwater nitrate attenuation in a regional system coupling hydrogeology with multi-isotopic methods: the case of Plana de Vic (Osona, Spain). Agr Ecosyst Environ 2009; 133:103-113.

Ouyang Y. Estimation of shallow groundwater discharge and nutrient into a river. Ecol Eng 2012; 38:101-104.

Pacioni E, Petitta M, Mariño M. Simulation by the IPTM-CS model of pesticides found in surface water and groundwater of the Fucino plain, Italy. IAHS-AISH Publication 2007; 314:188-196.

Perego A, Basile A, Bonfante A., De Mascellis R, Terribile F, Brenna S, Acutis M, Nitrate leaching under maize cropping systems in Po Valley (Italy). Agr Ecosyst Environ 2012; 147: 57-65.

Petelet-Giraud E, Claver G, Negrel P. Natural versus anthropogenic sources in the surface-and groundwater dissolved load of the Dommel river (Meuse basin): Constraints by boron and strontium isotopes and gadolinium anomaly. J Hydrol 2009; 369: 336-349.

Pellegrini L, Vercesi PL. I geositi della Provincia di Pavia. Luigi Ponzio e figli Editore, Pavia. (in Italian); 2005.

Petitta M, Fracchiolla D, Aravena R, Barbieri M. Application of isotopic and geochemical tools for the evaluation of nitrogen cycling in an agricultural basin, the Fucino Plain, Central Italy. J Hydrol 2009; 372:124-135. 
Pilla G, Sacchi E, Zuppi GM, Braga G, Ciancetti G. Hydrochemistry and isotope geochemistry as tools for groundwater hydrodynamic investigation in multilayer aquifers: a case study from Lomellina, Po plain, South-Western Lombardy, Italy. Hydrogeol J 2006; 14:795-808.

Pittman RJ, Hatzell HH, Oaksford ET. Spring contributions to water quantity and nitrate loads in the Suwannee river during base flow in July 1995. U.S. Geological Survey - Water Resources Investigations Report 97-4152; 1997.

Racchetti E, Bartoli M, Soana E, Longhi D, Christian RR, Pinardi M, Viaroli P. Influence of hydrological connectivity of riverine wetlands on nitrogen removal via denitrification. Biogeochemistry 2011; 103:335-354.

Reichard JS, Brown CM. Detecting groundwater contamination of a river in Georgia, USA using baseflow sampling. Hydrogeol J 2009; 17:735-747.

Ribbe L, Delgado P, Salgado E, Flügel WA. Nitrate pollution of surface water induced by agricultural non-point pollution in the Pocochay watershed, Chile. Desalination 2008; 226: 1320.

Rock L, Mayer B. Nitrogen budget for the Oldman River Basin, southern Alberta, Canada. Nutr Cycl Agroecosys 2006; 75:147-162.

Rosenberg DM, Berkes F, Bodaly RA, Hecky RE, Kelly CA, Rudd JWM. Large-scale impacts of hydroelectric development. Environ Rev 1997; 5:27-54.

Rozanski K, Araguás-Araguás L, Gonfiantini R. Isotopic patterns in modern global precipitation. In: Swart PK, Lohmann KC, McKenzie J, Savin S, editors. Climate Change in Continental Isotopic Records, Geophys. Monogr. Ser.,78, AGU, Washington, D. C; 1993. p. 1-36,

Sacchi E, Acutis M, Batoli M, Brenna S, Delconte CA, Laini A, Pennini M. Origin and fate of nitrates in groundwater from the central Po plain: insights from isotopic investigations. Appl Geochem in press.

Saccon P, Leis A, Marca A, Kaiser J, Campisi L, Böttcher ME, et al. Multi-isotope approach for the identification and characterisation of nitrate pollution sources in the Marano lagoon (Italy) and parts of its catchment area. Appl Geochem in press.

Sebilo M, Billen G, Grably M, Mariotti A. Isotopic composition of nitrate-nitrogen as a marker of riparian and benthic denitrification at the scale of the whole seine River system. Biogeochemistry 2003; 63:35-51.

Seiler RL. Combined use of ${ }^{15} \mathrm{~N}$ and ${ }^{18} \mathrm{O}$ of nitrate and ${ }^{11} \mathrm{~B}$ to evaluate nitrate contamination in groundwater. Appl Geochem 2005; 20:1626-1636.

Silva SR, Kendall C, Wilkison DH, Ziegler AC, Chang CCY, Avanzino RJ. A new method for collection of nitrate from fresh water and the analysis of nitrogen and oxygen isotope ratios. $J$ Hydrol 2000; 228: 22-36.

Smith VH, Tilman GD, Nekola JC. Eutrophication: impacts of excess nutrient imputs on freshwater, marine, and terrestrial ecosystems. Environ Pollut 1999; 100:179-196.

Smith VH. Eutrophication of freshwater and coastal marine ecosystems: a global problem. Environ Sci Pollut Res Int 2003; 10:126-139.

Soana E, Racchetti E, Laini A, Bartoli M, Viaroli P. Soil budget, net export, and potential sinks of nitrogen in the lower Oglio river watershed (Northern Italy). Clean - Soil Air Water 2011; 39:956-965. 
Sophocleous M. Interactions between groundwater and surface water: the state of the science. Hydrogeol J 2002; 10: 52-67.

Tirez K, Brusten W, Widory D, Petelet E, Bregnot A, Xue J., et al. Boron isotope ratio $\left(\delta^{11} \mathrm{~B}\right)$ measurements in Water Framework Directive monitoring programs: comparison between double focusing sector field ICP and thermal ionization mass spectrometry. J Anal At Spectrom 2010; 25:964-974.

Van Grinsven HJM, Ward MH, Benjamin N, De Kok TM. Does the evidence about health risk associated with nitrate ingestion warrant an increase of the nitrate standard for drinking water? Environ Health: A Global Access Science Sourc 2006; 5:26.

Vitousek PM, Aber JD, Howart RW, Likens GE, Matson PA, Schindler DW, et al. Human alteration of the global nitrogen cycle: sources and consequences. Ecol Appl 1997; 7:737-750.

Vörösmarty CJ, Sahagian D. Anthropogenic disturbance of the terrestrial water cycle. BioScience 2000; 50:753-756.

Voss M, Deutsch B, Elmgren R, Humborg C, Kuuppo P, Pastuszak M, Rolff C, Schulte U. Source identification of nitrate by means of isotopic tracers in the Baltic Sea catchments. Biogeosciences 2006; 3:663-676.

Ward MH, De Kok TM, Levallois P, Brender J, Gulis G, Nolan BT, Van Derslice J. Workgroup report: Drinking-water nitrate and health-recent findings and research needs. Environ Health Persp 2005; 113:1607-1614.

Weltje GJ. End-member modeling of compositional data: numerical-statistical algorithms for solving the explicit mixing model. Mat Geol 1997; 29:503-549.

Widory, D, Petelet-Giraud E, Négrel P, Ladouche B. Tracking the sources of nitrate in groundwater using coupled nitrogen and boron isotopes: a synthesis. Environ Sci Technol 2005; 39:539-548.

Widory D, Petelet-Giraud E, Brenot A, Bronders J, Tirez K, Boeckx P. Improving the management of nitrate pollution in water by the use of isotope monitoring: the delta $\mathrm{N}-15$, delta $\mathrm{O}-18$ and delta B-11 triptych. Isot Environ Healt S 2012; 49:29-47.

Wollheim WM, Vörösmarty CJ, Bouwman AF, Green P, Harrison J, Linder E et al. Global N removal by freshwater aquatic systems using a spatially distributed, within-basin approach. Global Biogeochem Cy 2008; 22 art. no. GB2026

Xue D, Botte J, De Baets B, Accoe F, Nestler A, Taylor P, Van Cleemput O. Present limitation and future prospects of stable isotope methods for nitrate source identification in surface-and groundwater. Water Res 2009; 43:1159-1170.

Zoppini A, Pettine M, Totti C, Puddu A, Artegiani A, Pagnotta R. Nutrients, standing crop, and primary production in western coastal waters of the Adriatic Sea. Estuar Coast Shelf Sci 1995; 41:493-513. 


\section{List of tables}

Tab. 1 Summary of the parameters analysed for each sampling campaign. $\mathrm{T}=$ Temperature; $\mathrm{EC}=$ Electrical conductivity; DIC = Dissolved Inorganic Carbon; Q = Discharge

Tab. 2. Analytical data. DIC is expressed as $\mathrm{mg} \mathrm{L}^{-1}$ of $\mathrm{HCO}_{3}^{-} \cdot *=$ hydrochemical data provided by ARPA Lombardy

Tab. 3. Results of the multiple linear regression, using the selected hydrochemical and isotopic variables, and of the EMMA for the Oglio River. Calculated flows $\left(\mathrm{Q}_{\mathrm{SW}}\right.$ and $\left.\mathrm{Q}_{\mathrm{GW}}\right)$ are in $\mathrm{m}^{3} \mathrm{~s}^{-1}$. Grey rows correspond to discarded data (see text for explanation). 
Tab. 1

\begin{tabular}{|c|c|c|c|c|c|c|}
\hline \multirow{2}{*}{$\begin{array}{l}\text { Sampling } \\
\text { campaign }\end{array}$} & \multirow[t]{2}{*}{ Date } & \multirow{2}{*}{$\begin{array}{l}\text { Hydrochemical } \\
\text { data }\end{array}$} & \multirow{2}{*}{$\begin{array}{l}\text { Hydrological } \\
\text { data }\end{array}$} & \multicolumn{3}{|c|}{ Isotope data } \\
\hline & & & & $\mathrm{H}_{2} \mathrm{O}$ & $\mathrm{NO}_{3}^{-}$ & $\mathrm{B}$ \\
\hline $\begin{array}{l}\text { August } 2009 \\
\text { (summer) }\end{array}$ & $5-7 / 8$ & $\begin{array}{l}\mathrm{T}, \mathrm{EC}, \mathrm{DIC}, \mathrm{NO}_{3}^{-} \\
\mathrm{Cl}^{-}, \mathrm{SO}_{4}^{2-}\end{array}$ & Q & & $\begin{array}{l}\delta^{15} \mathrm{~N}_{\mathrm{NO} 3}, \delta^{18} \mathrm{O}_{\mathrm{NO} 3} \\
\text { (only middle and } \\
\text { downstream reaches of } \\
\text { the Oglio River) }\end{array}$ & \\
\hline $\begin{array}{l}\text { December } \\
2009 \\
\text { (autumn) }\end{array}$ & $30 / 11-3 / 12$ & $\begin{array}{l}\mathrm{T}, \mathrm{EC}, \mathrm{DIC}, \mathrm{NO}_{3}^{-} \\
\mathrm{Cl}^{-}, \mathrm{SO}_{4}^{2-}\end{array}$ & Q & & $\begin{array}{l}\delta^{15} \mathrm{~N}_{\mathrm{NO} 3} \\
\delta^{18} \mathrm{O}_{\mathrm{NO} 3}\end{array}$ & \\
\hline $\begin{array}{l}\text { February } 2010 \\
\text { (winter) }\end{array}$ & $8-11 / 2$ & $\begin{array}{l}\mathrm{T}, \mathrm{EC}, \mathrm{DIC}, \mathrm{NO}_{3}^{-} \\
\mathrm{Cl}^{-}, \mathrm{SO}_{4}^{2-}\end{array}$ & Q & & $\begin{array}{l}\delta^{15} \mathrm{~N}_{\mathrm{NO} 3}, \delta^{18} \mathrm{O}_{\mathrm{NO} 3} \\
\text { (only middle and } \\
\text { downstream reaches of } \\
\text { the Oglio River) }\end{array}$ & \\
\hline $\begin{array}{l}\text { July } 2010 \\
\text { (summer) }\end{array}$ & $28-30 / 7$ & $\begin{array}{l}\mathrm{T}, \mathrm{EC}, \mathrm{DIC}, \mathrm{NO}_{3}^{-} \\
\mathrm{Cl}^{-}, \mathrm{SO}_{4}^{2-}, \mathrm{B}, \mathrm{Sr}\end{array}$ & $\mathrm{Q}$ & $\begin{array}{l}\delta \mathrm{D}_{\mathrm{H} 2 \mathrm{O}} \\
\delta^{18} \mathrm{O}_{\mathrm{H} 2 \mathrm{O}}\end{array}$ & $\begin{array}{l}\delta^{15} \mathrm{~N}_{\mathrm{NO} 3} \\
\delta^{18} \mathrm{O}_{\mathrm{NO} 3}\end{array}$ & $\delta^{11} \mathrm{~B}$ \\
\hline $\begin{array}{l}\text { December } \\
2011 \text { (winter) }\end{array}$ & $29 / 11-2 / 12$ & $\mathrm{~B}, \mathrm{Sr}$ & & & & $\delta^{11} \mathrm{~B}$ \\
\hline
\end{tabular}




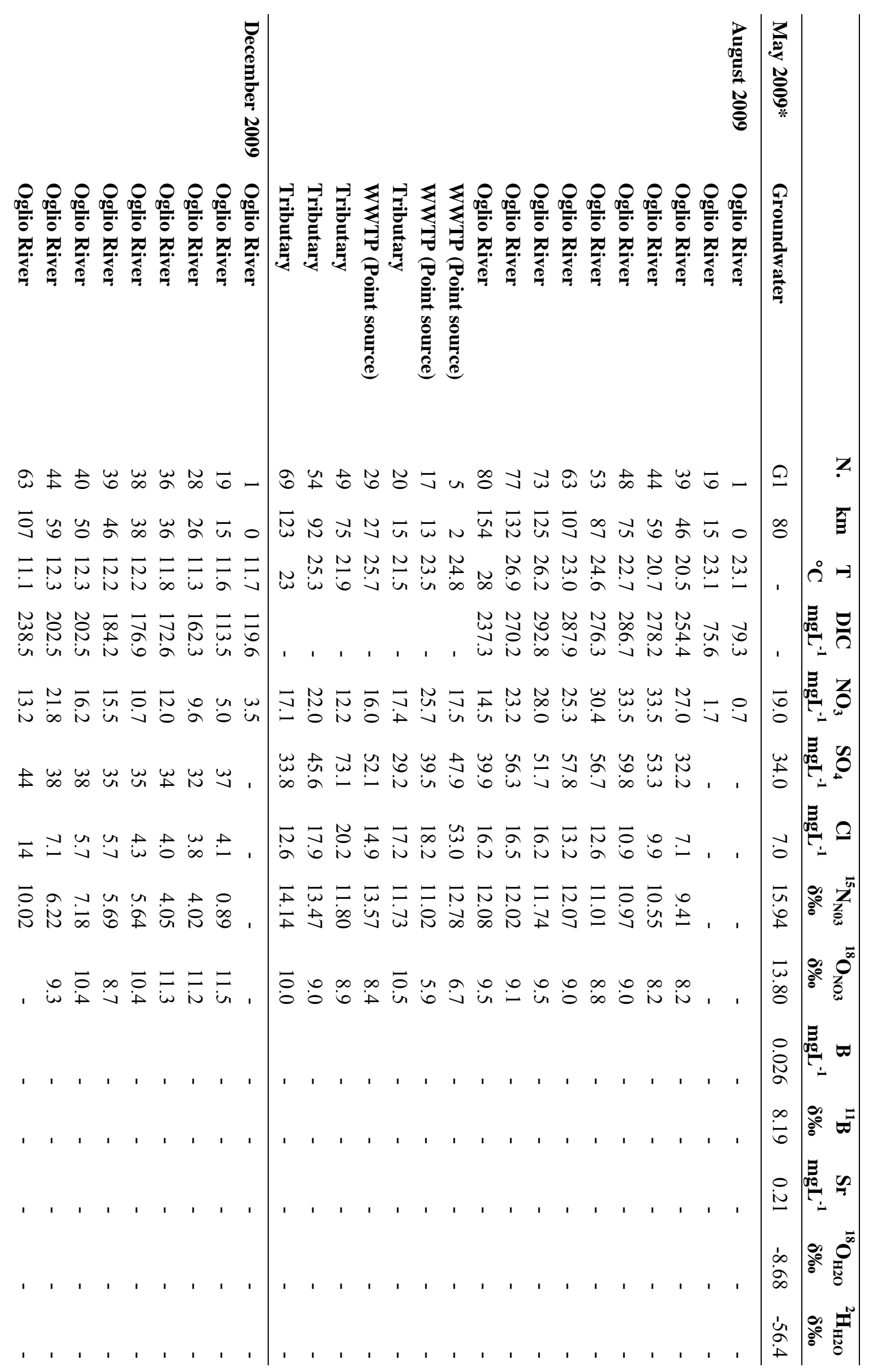




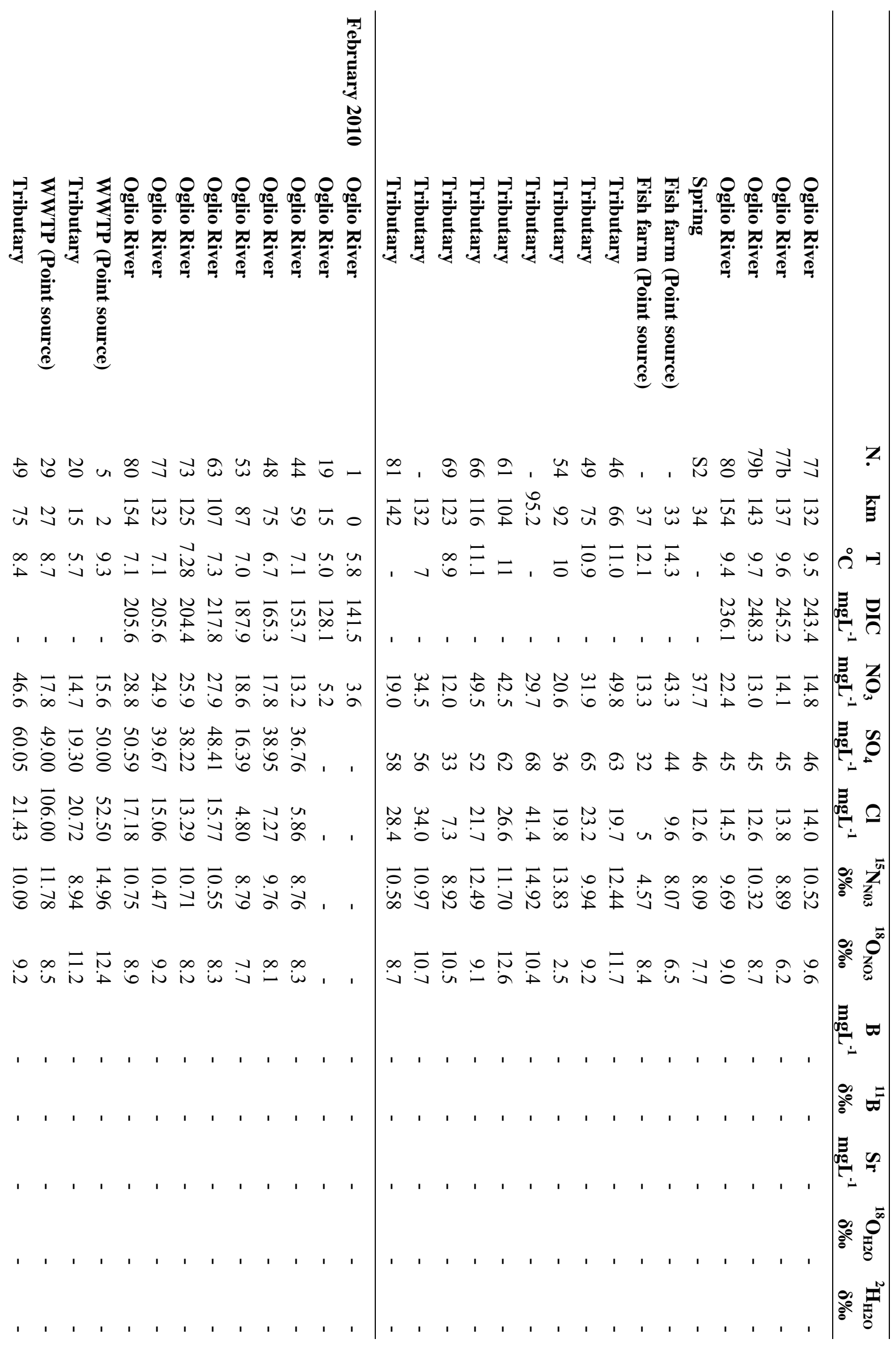




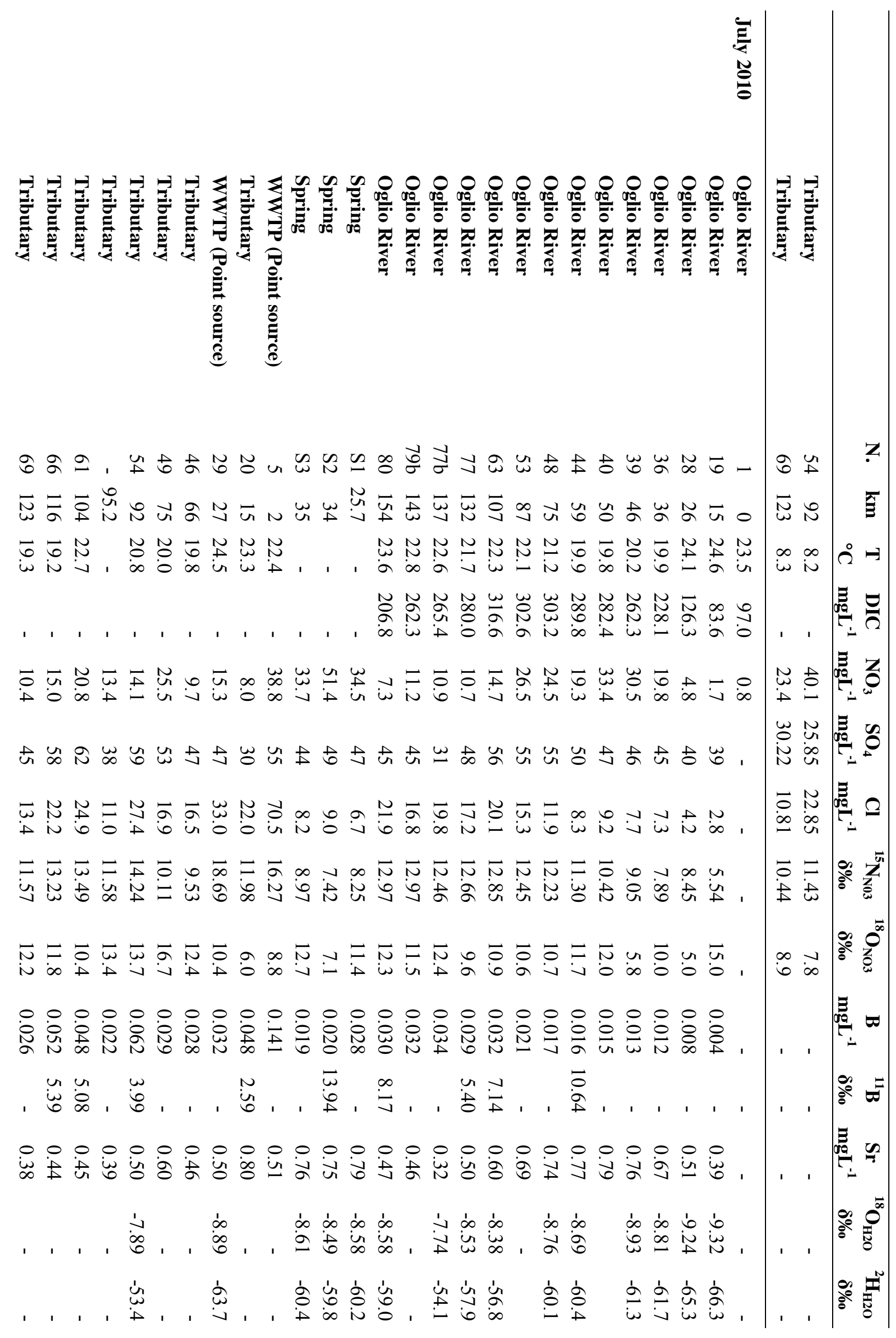




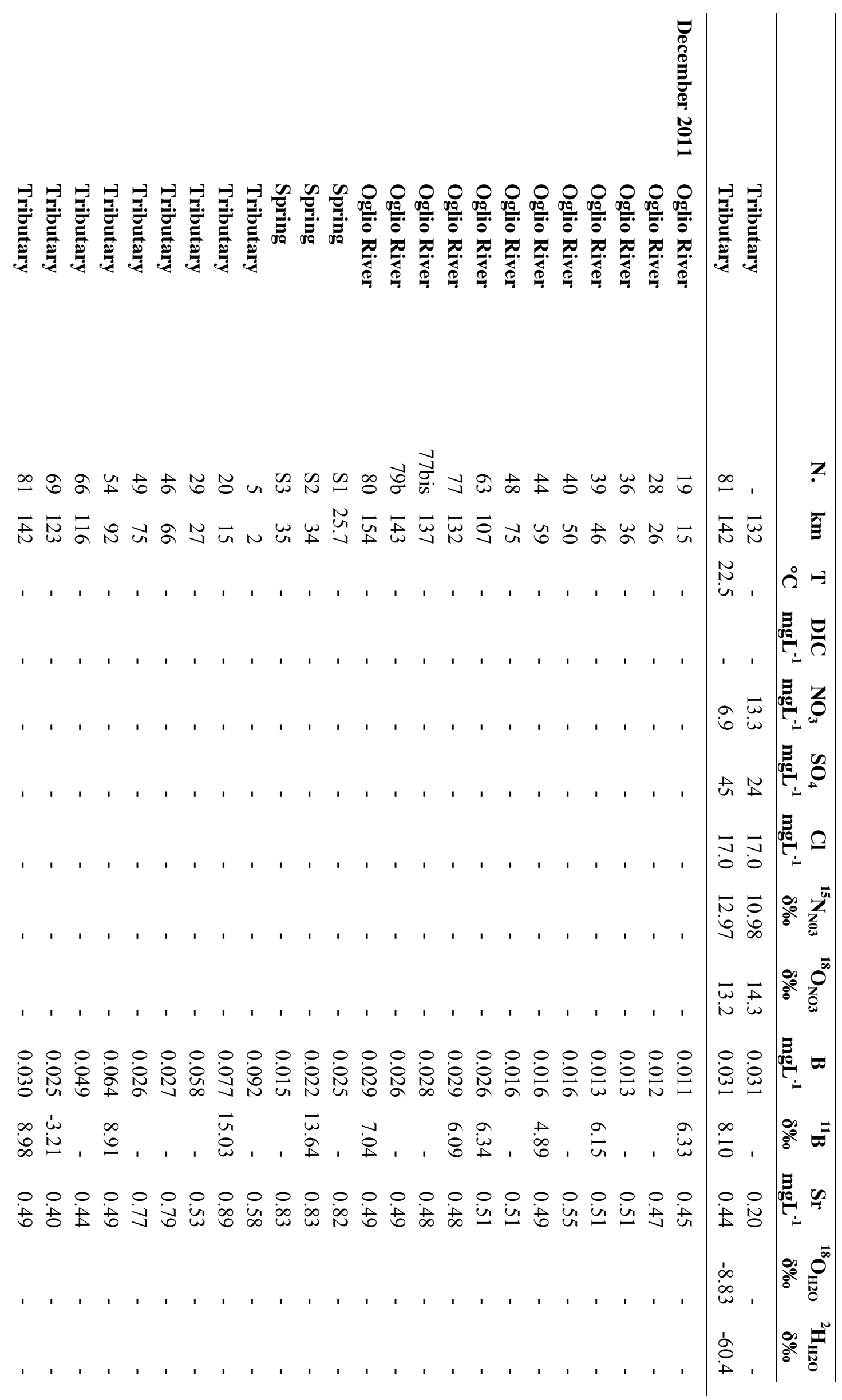


Tab.3

\begin{tabular}{|c|cc|cc|c|cc|c|c|c|}
\hline $\begin{array}{c}\text { reach }(\mathrm{km}) \\
15-26\end{array}$ & $\mathrm{Q}_{1}$ & $\mathrm{C}_{1}$ & $\mathrm{Q}_{2}$ & $\mathrm{C}_{2}$ & $\mathrm{C}_{\mathrm{GW}}$ & $\mathrm{Q}_{2}{ }^{*}\left(\mathrm{C}_{2}-\mathrm{C}_{\mathrm{GW}}\right)$ & $\mathrm{Q}_{1}{ }^{*}\left(\mathrm{C}_{\mathrm{GW}}-\mathrm{C}_{1}\right)$ & $\mathrm{C}_{\mathrm{SW}}$ & $\mathbf{Q}_{\mathrm{sw}}$ & $\mathbf{Q}_{\mathrm{GW}}$ \\
\hline $\mathrm{EC}\left(\mathrm{mS} \mathrm{m}^{-1}\right)$ & 36.84 & 20.50 & 18.55 & 28.7 & 54.8 & -484.8 & 1264.8 & 20.50 & -22.72 & 4.43 \\
$\mathrm{Cl}\left(\mathrm{g} \mathrm{m}^{-3}\right)$ & 36.84 & 2.80 & 18.55 & 4.2 & 8.0 & -69.9 & 190.3 & 2.80 & -23.32 & 5.03 \\
$\mathrm{SO}_{4}\left(\mathrm{~g} \mathrm{~m}^{-3}\right)$ & 36.84 & 39.0 & 18.55 & 40 & 46.7 & -123.7 & 282.4 & 39.0 & .20 .71 & 2.42 \\
$\delta^{18} \mathrm{O}(\%)$ & 36.84 & -9.32 & 18.55 & -9.24 & -8.6 & -12.6 & 27.9 & -9.32 & -20.23 & 1.94 \\
$\delta \mathrm{D}(\%)$ & 36.84 & -66.31 & 18.55 & -65.35 & -60.14 & -96.6 & 227.3 & -66.31 & -21.17 & 2.88 \\
$\mathrm{~B}\left(\mathrm{~g} \mathrm{~m}^{-3}\right)$ & 36.84 & 0.004 & 18.55 & 0.008 & 0.022 & -0.3 & 0.7 & 0.004 & -22.54 & 4.25 \\
$\mathrm{Sr}\left(\mathrm{g} \mathrm{m}^{-3}\right)$ & 36.84 & 0.394 & 18.55 & 0.508 & 0.770 & -4.9 & 13.9 & 0.394 & -23.91 & 5.62 \\
\hline
\end{tabular}

\begin{tabular}{|c|cc|cc|c|cc|c|c|c|}
\hline $\begin{array}{c}\text { reach }(\mathrm{km}) \\
26-36\end{array}$ & $\mathrm{Q}_{1}$ & $\mathrm{C}_{1}$ & $\mathrm{Q}_{2}$ & $\mathrm{C}_{2}$ & $\mathrm{C}_{\mathrm{GW}}$ & $\mathrm{Q}_{2}{ }^{*}\left(\mathrm{C}_{2}-\mathrm{C}_{\mathrm{GW}}\right)$ & $\mathrm{Q}_{1}{ }^{*}\left(\mathrm{C}_{\mathrm{GW}}-\mathrm{C}_{1}\right)$ & $\mathrm{C}_{\mathrm{SW}}$ & $\mathbf{Q}_{\mathrm{SW}}$ & $\mathbf{Q}_{\mathrm{GW}}$ \\
\hline $\mathrm{EC}\left(\mathrm{mS} \mathrm{m}^{-1}\right)$ & 18.55 & 28.7 & 6.62 & 45.8 & 54.8 & -59.8 & 484.8 & 28.70 & -16.26 & 4.33 \\
$\mathrm{Cl}\left(\mathrm{g} \mathrm{m}^{-3}\right)$ & 18.55 & 4.2 & 6.62 & 7.3 & 8.0 & -4.4 & 69.9 & 4.20 & -17.38 & 5.45 \\
$\mathrm{SO}_{4}\left(\mathrm{~g} \mathrm{~m}^{-3}\right)$ & 18.55 & 40.0 & 6.62 & 45.0 & 46.7 & -11.0 & 123.7 & 40.00 & -16.90 & 4.96 \\
$\delta^{18} \mathrm{O}(\%)$ & 18.55 & -9.24 & 6.62 & -8.81 & -8.6 & -1.6 & 12.6 & -9.24 & -16.13 & 4.20 \\
$\delta \mathrm{D}(\%)$ & 18.55 & -65.35 & 6.62 & -61.70 & -60.14 & -10.4 & 96.6 & -65.35 & -16.56 & 4.63 \\
$\mathrm{~B}\left(\mathrm{~g} \mathrm{~m}^{-3}\right)$ & 18.55 & 0.008 & 6.62 & 0.012 & 0.022 & -0.1 & 0.3 & 0.008 & -13.48 & 1.55 \\
$\mathrm{Sr}\left(\mathrm{g} \mathrm{m}^{-3}\right)$ & 18.55 & 0.508 & 6.62 & 0.673 & 0.770 & -0.6 & 4.9 & 0.508 & -16.10 & 4.17 \\
\hline
\end{tabular}

\begin{tabular}{|c|cc|cc|c|cc|c|c|c|}
\hline $\begin{array}{c}\text { reach }(\mathrm{km}) \\
36-46\end{array}$ & $\mathrm{Q}_{1}$ & $\mathrm{C}_{1}$ & $\mathrm{Q}_{2}$ & $\mathrm{C}_{2}$ & $\mathrm{C}_{\mathrm{GW}}$ & $\mathrm{Q}_{2} *\left(\mathrm{C}_{2}-\mathrm{C}_{\mathrm{GW}}\right)$ & $\mathrm{Q}_{1}{ }^{*}\left(\mathrm{C}_{\mathrm{GW}}-\mathrm{C}_{1}\right)$ & $\mathrm{C}_{\mathrm{SW}}$ & $\mathbf{Q}_{\mathrm{SW}}$ & $\mathbf{Q}_{\mathrm{GW}}$ \\
\hline $\mathrm{EC}\left(\mathrm{mS} \mathrm{m}^{-1}\right)$ & 6.62 & 45.8 & 8.58 & 51.20 & 54.8 & -31.17 & 59.80 & 45.80 & -3.17 & 5.13 \\
$\mathrm{Cl}\left(\mathrm{g} \mathrm{m}^{-3}\right)$ & 6.62 & 7.3 & 8.58 & 7.70 & 8.0 & -2.29 & 4.41 & 7.30 & -3.19 & 5.15 \\
$\mathrm{SO}_{4}\left(\mathrm{~g} \mathrm{~m}^{-3}\right)$ & 6.62 & 45.0 & 8.58 & 46.00 & 46.7 & -5.72 & 11.03 & 45.00 & -3.19 & 5.15 \\
$\delta^{18} \mathrm{O}(\%)$ & 6.62 & -8.81 & 8.58 & -8.93 & -8.6 & -3.20 & 1.65 & -8.81 & 6.25 & -4.29 \\
$\delta \mathrm{D}(\%)$ & 6.62 & -61.70 & 8.58 & -61.30 & -60.14 & -10.01 & 10.35 & -61.70 & -0.22 & 2.18 \\
$\mathrm{~B}\left(\mathrm{~g} \mathrm{~m}^{-3}\right)$ & 6.62 & 0.012 & 8.58 & 0.013 & 0.022 & -0.08 & 0.07 & 0.012 & 1.01 & 0.95 \\
$\mathrm{Sr}\left(\mathrm{g} \mathrm{m}^{-3}\right)$ & 6.62 & 0.673 & 8.58 & 0.765 & 0.770 & -0.04 & 0.64 & 0.673 & -6.18 & 8.14 \\
\hline
\end{tabular}

\begin{tabular}{|c|cc|cc|c|cc|c|c|c|}
\hline $\begin{array}{c}\text { reach }(\mathrm{km}) \\
59-154\end{array}$ & $\mathrm{Q}_{1}$ & $\mathrm{C}_{1}$ & $\mathrm{Q}_{2}$ & $\mathrm{C}_{2}$ & $\mathrm{C}_{\mathrm{GW}}$ & $\mathrm{Q}_{2} *\left(\mathrm{C}_{2}-\mathrm{C}_{\mathrm{GW}}\right)$ & $\mathrm{Q}_{1} *\left(\mathrm{C}_{\mathrm{GW}}-\mathrm{C}_{1}\right)$ & $\mathrm{C}_{\mathrm{SW}}$ & $\mathbf{Q}_{\mathrm{SW}}$ & $\mathbf{Q}_{\mathrm{GW}}$ \\
\hline $\mathrm{EC}$ & 19.69 & 57.10 & 69.59 & 51.20 & 49.8 & 97.4 & -143.7 & 61.8 & -43.0 & 92.9 \\
$\mathrm{Cl}$ & 19.69 & 8.30 & 69.59 & 21.90 & 7.0 & 1036.9 & -25.6 & 18.48 & 91.62 & -41.72 \\
$\mathrm{SO}_{4}$ & 19.69 & 50.00 & 69.59 & 45.00 & 34 & 765.5 & -315.0 & 47.89 & -148.60 & 198.50 \\
$\delta^{18} \mathrm{O}$ & 19.69 & -8.69 & 69.59 & -8.58 & -8.68 & 7.3 & 0.2 & -8.36 & 7.58 & 42.32 \\
$\delta \mathrm{D}$ & 19.69 & -60.41 & 69.59 & -59.05 & -56.37 & -186.3 & 79.6 & -56.91 & 25.17 & 24.73 \\
$\mathrm{~B}$ & 19.69 & 0.016 & 69.59 & 0.030 & 0.0255 & 0.3 & 0.2 & 0.04 & 46.46 & 3.44 \\
$\mathrm{Sr}$ & 19.69 & 0.769 & 69.59 & 0.474 & 0.2089 & 18.45 & -11.03 & 0.43 & 60.57 & -10.67 \\
\hline
\end{tabular}




\section{List of Figures}

Fig 1. a) Location of the Po River watershed and of the Oglio River watershed (investigated area) in Northern Italy. $\mathrm{BG}=$ Bergamo; $\mathrm{BS}=$ Brescia $; \mathrm{CR}=$ Cremona; $\mathrm{MN}=$ Mantova; $\mathrm{MI}=$ Milan; $\mathrm{PV}$ $=$ Pavia. b) Location of the sampling stations selected for isotopic analyses in the Oglio River watershed. Grey areas $=$ Nitrate Vulnerable Zones. The map also shows the approximate length of the upstream, middle and downstream reaches and the position of the "springs belt".

Fig. 2. a) Seasonal discharge trends in the Oglio River. b) $\mathrm{NO}_{3}{ }^{-}$concentrations in the Oglio river. The white, grey and black triangles indicate different reaches in the Oglio River, varying in length in the different sampling campaigns (see text for explanation). c) $\mathrm{NO}_{3}{ }^{-}$concentrations in spring waters, groundwater, natural and artificial tributaries, WWTPs and other inputs to the Oglio River. Symbols refer to the mean value; bars indicate minimum and maximum values.

Fig. 3. a) $\mathrm{Cl}^{-}, \mathrm{SO}_{4}{ }^{2-}, \mathrm{B}$ and $\mathrm{Sr}$ contents in the Oglio River water. b) $\mathrm{Cl}^{-}, \mathrm{SO}_{4}{ }^{2-}, \mathrm{B}$ and $\mathrm{Sr}$ contents in spring waters, natural and artificial tributaries, WWTPs and other inputs to the Oglio River. Symbols refer to the mean value; bars indicate minimum and maximum values.

Fig. 4. a) Stable isotopes of the water molecule in the Oglio River water, plotted versus distance from the Iseo Lake. b) Stable isotopes of the water molecule in the Oglio River water, in springs and in tributaries. The white, grey and black symbols differentiate the Oglio River reaches, as defined based on nitrate concentrations (see text for explanation and Fig. 2b).

Fig. 5. $\mathrm{NO}_{3}{ }^{-}$isotopic composition in the Oglio River water and in springs. The white, grey and black symbols indicate different reaches in the Oglio River, as defined based on nitrate concentrations (see text for explanation and Fig. 2b). SF = Synthetic fertilizers; Nit. = Evolution during nitrification; $\mathrm{MSF}=$ Mineralised synthetic fertilizers; $\mathrm{SOM}=$ Soil organic matter; $\mathrm{AOM}=$ 
Anthropogenic organic matter (sewage and manure); Denit. = Evolution during denitrification. Compositional fields after Clark and Fritz (1997) and Kendall (1998).

Fig. 6. $\mathrm{NO}_{3}{ }^{-}$isotopic composition in tributaries and springs. The white, grey and black symbols indicate different reaches in the Oglio River, as defined based on nitrate concentrations (see text for explanation and Fig. 2b). SF = Synthetic fertilizers; Nit. = Evolution during nitrification; MSF $=$ Mineralised synthetic fertilizers; $\mathrm{SOM}=$ Soil organic matter; $\mathrm{AOM}=$ Anthropogenic organic matter (sewage and manure); Denit. = Evolution during denitrification. Compositional fields after Clark and Fritz (1997) and Kendall (1998).

Fig. 7. $\delta^{11} \mathrm{~B} v s$ 1/B data. Grey symbols $=$ data from Sacchi et al. (in press). 


\section{Figure 1}

Click here to download Figure: Figure 1.docx

Fig.1

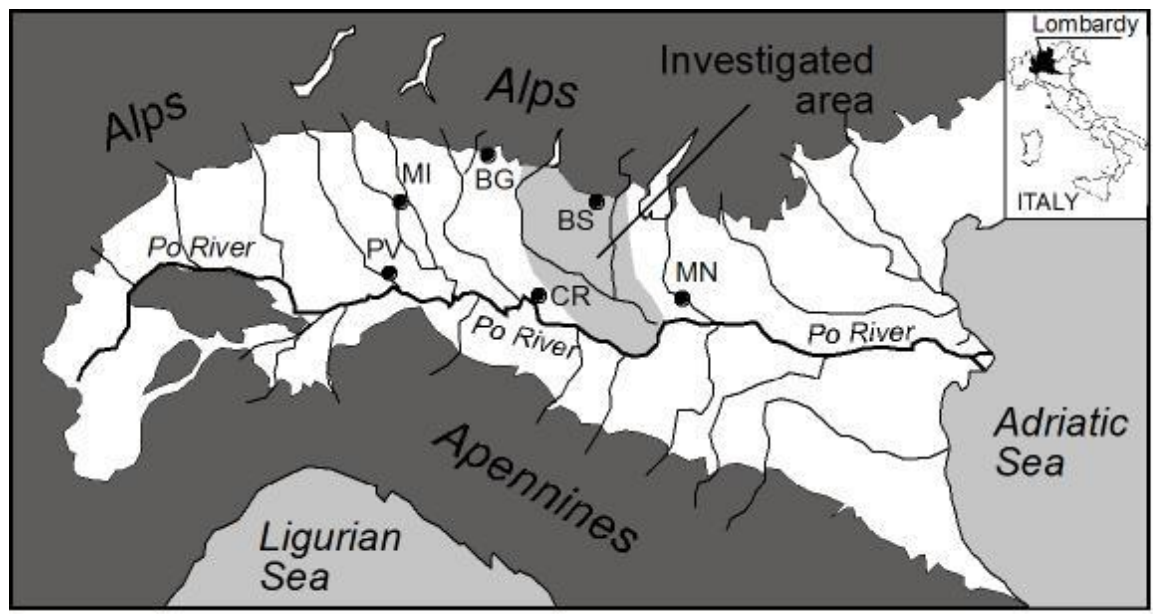

a

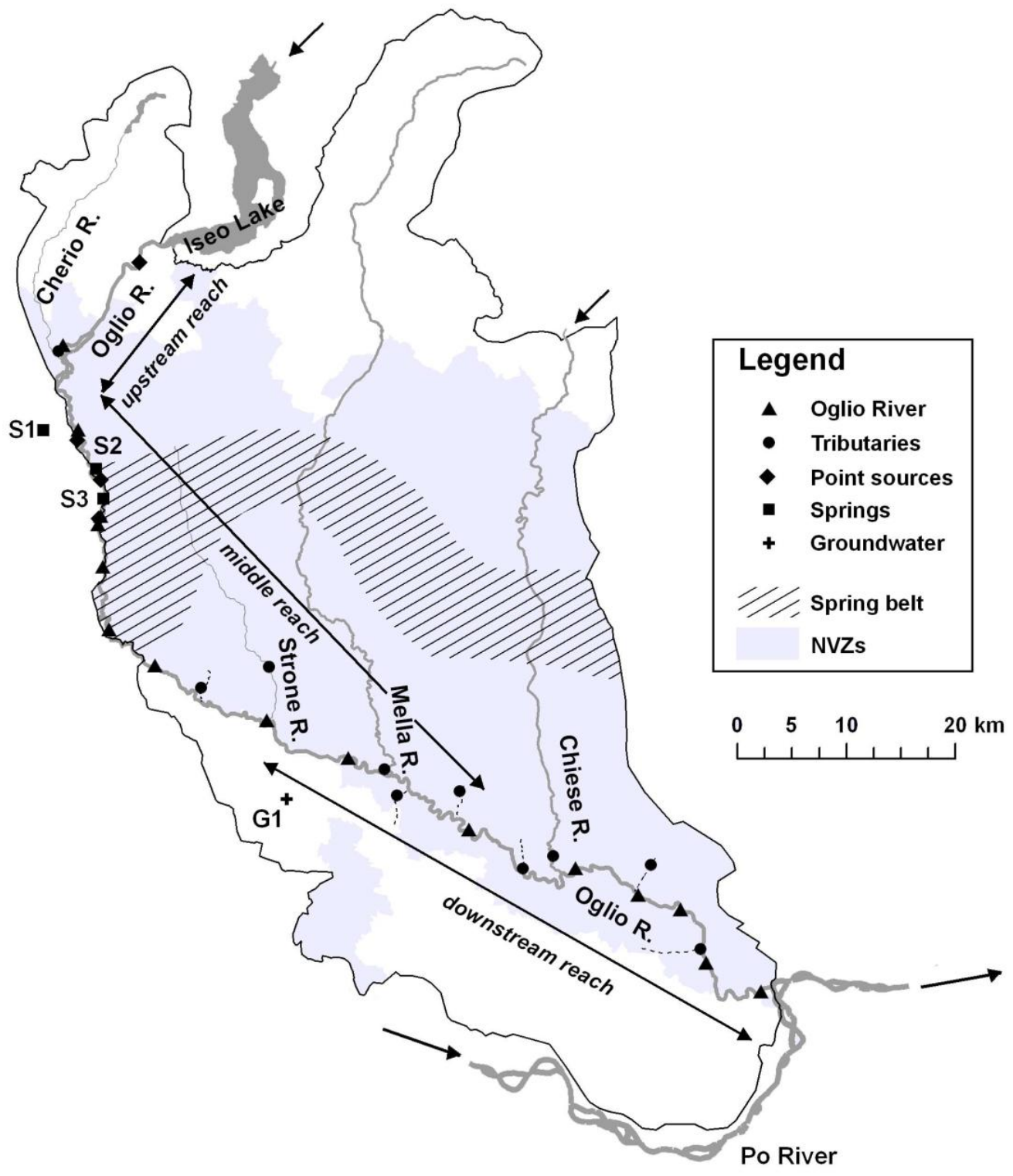


Figure 2

Click here to download Figure: Figure 2.docx

Fig. 2
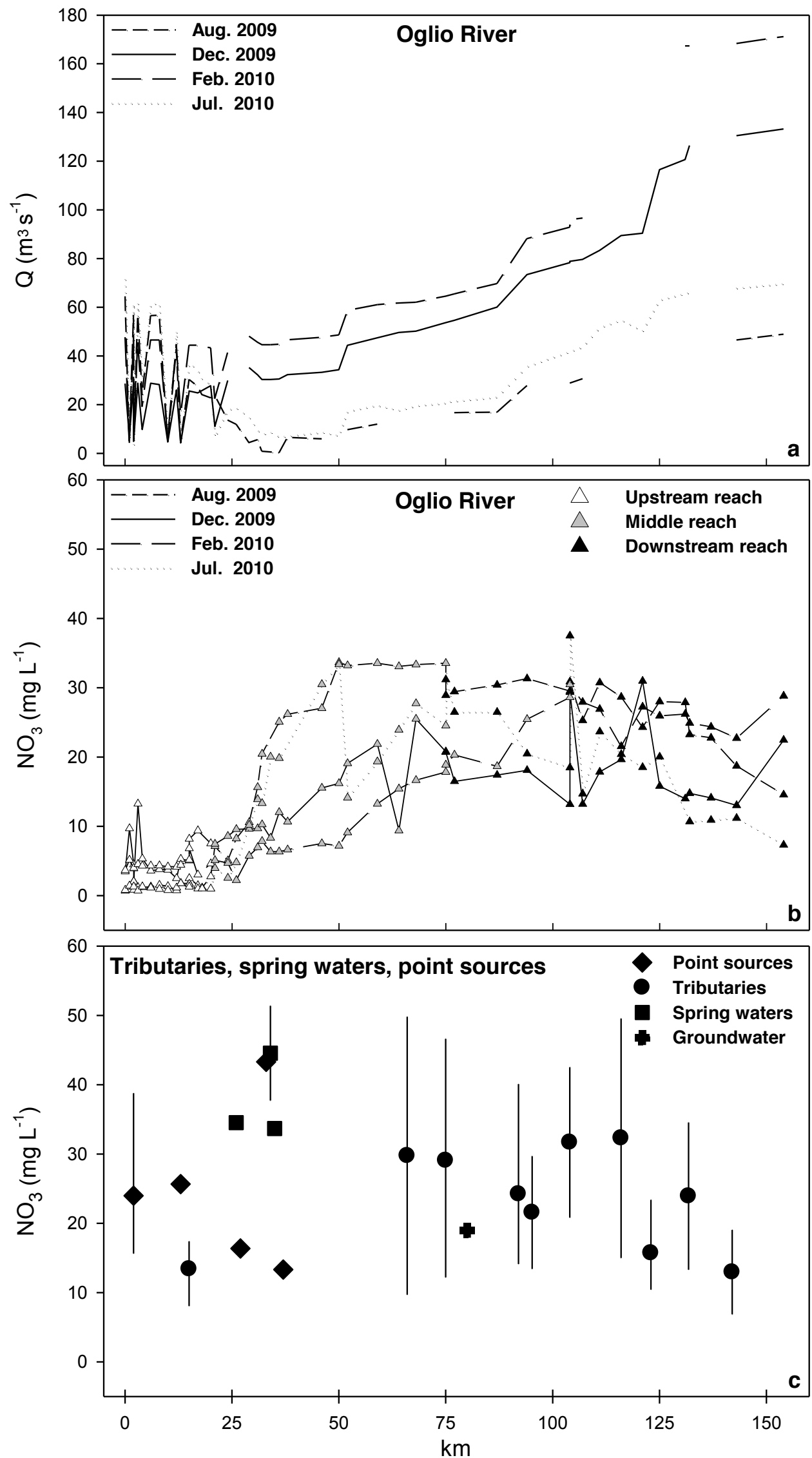
Figure 3

Click here to download Figure: Figure 3.docx

Fig. 3a
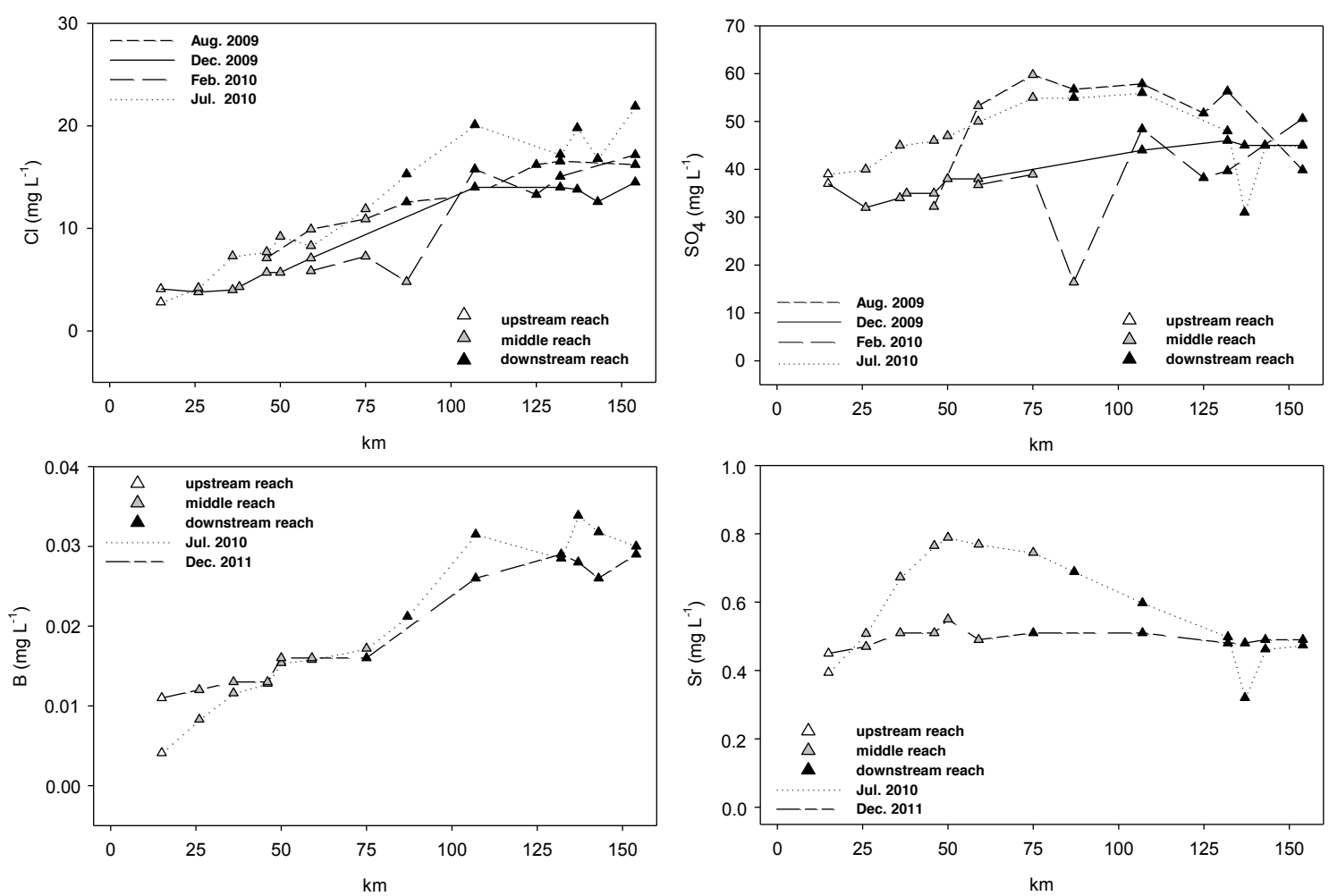

Fig. 3b
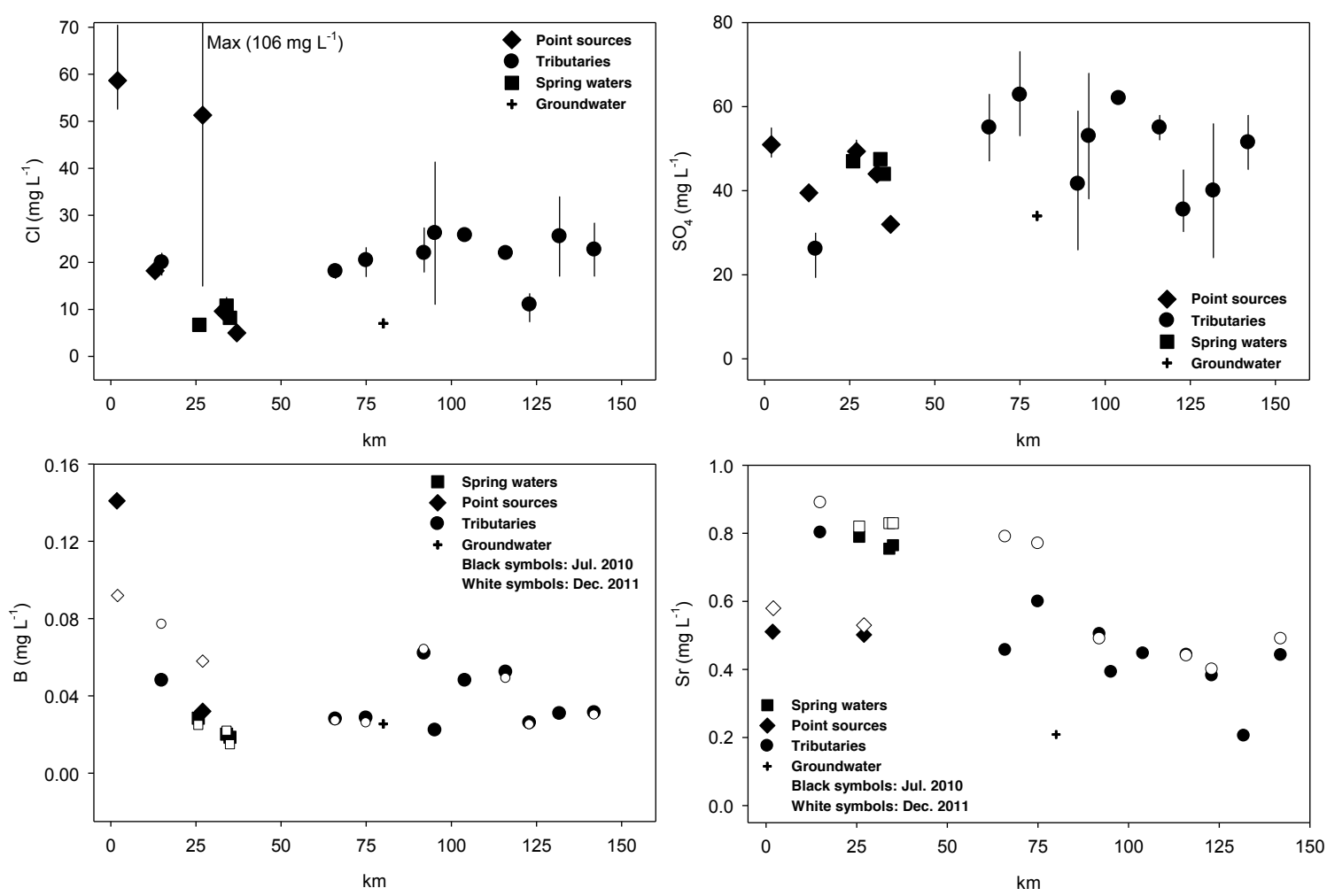
Figure 4

Click here to download Figure: Figure 4.docx

Fig. 4
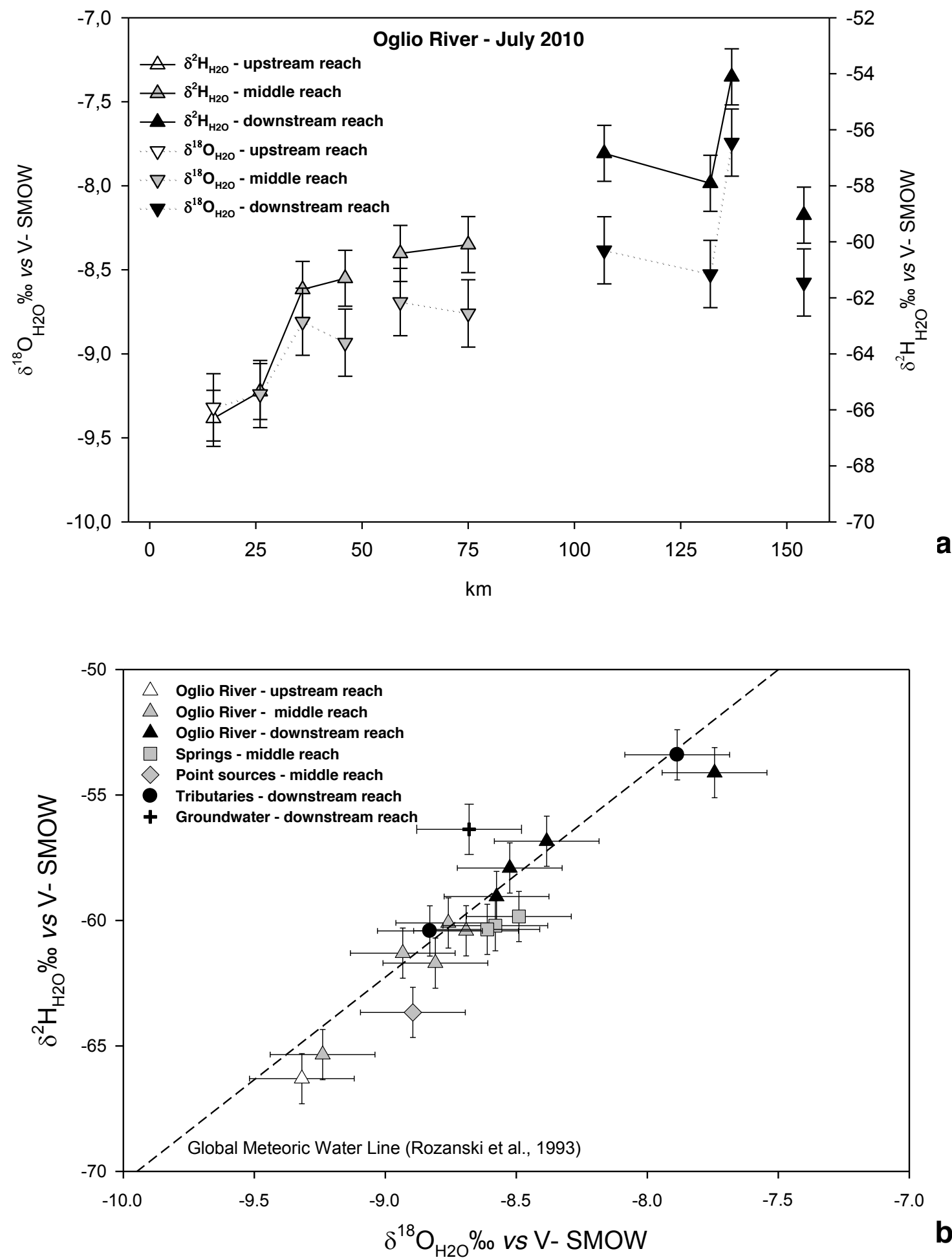


\section{Figure 5}

Click here to download Figure: Figure 5.docx

Fig. 5
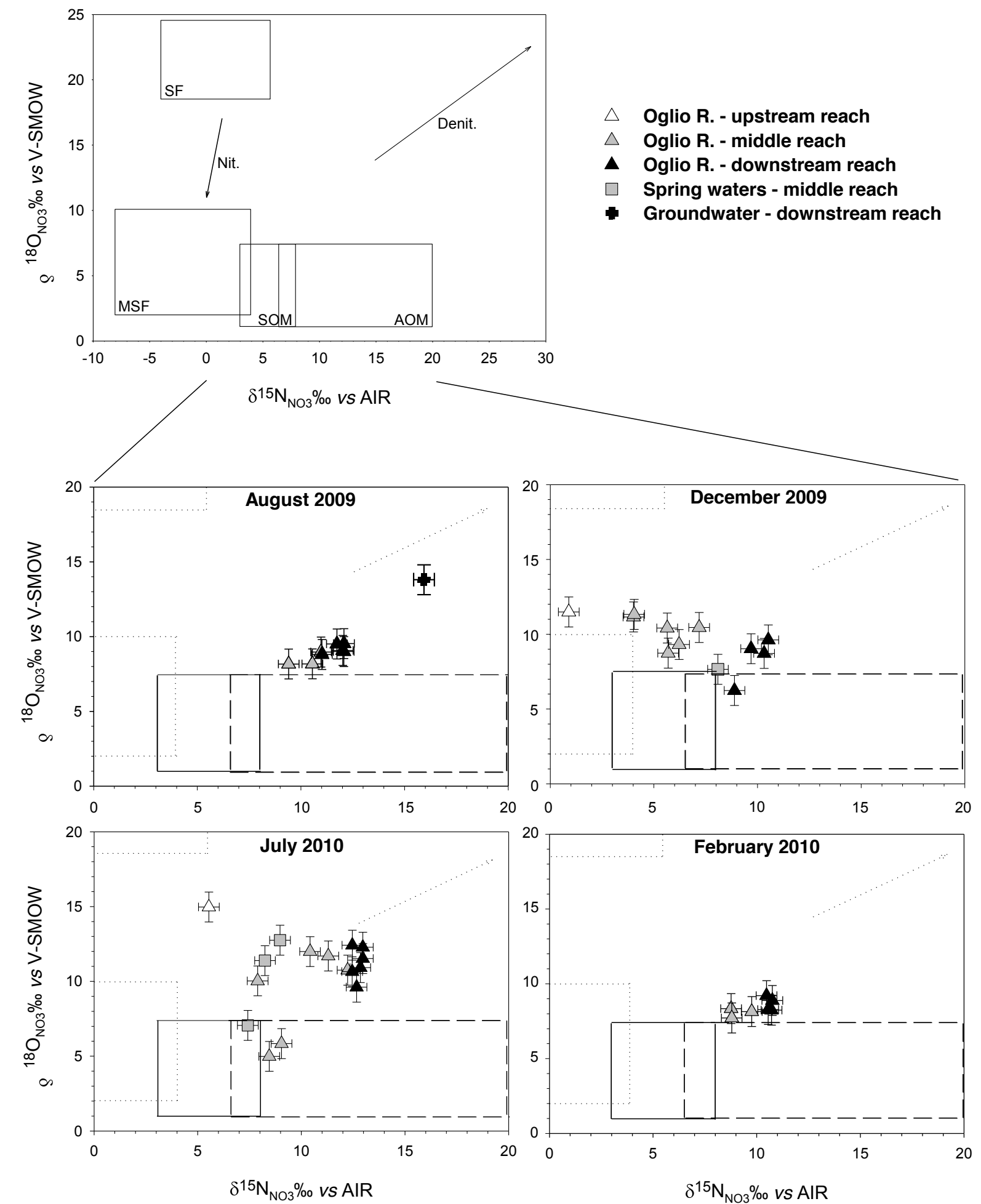
Figure 6

Click here to download Figure: Figure 6.docx

Fig. 6
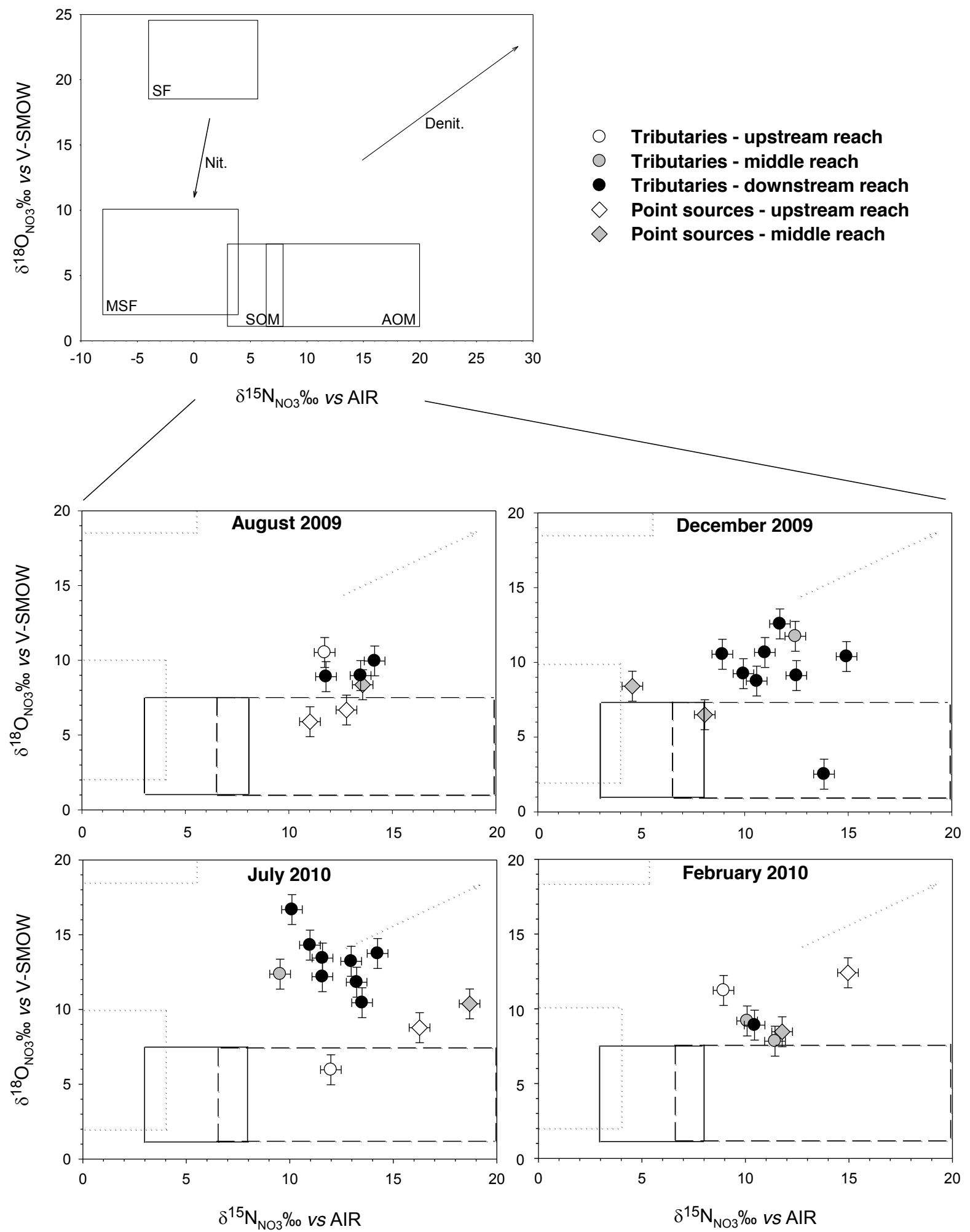
Figure 7

Click here to download Figure: Figure 7.docx

Fig. 7

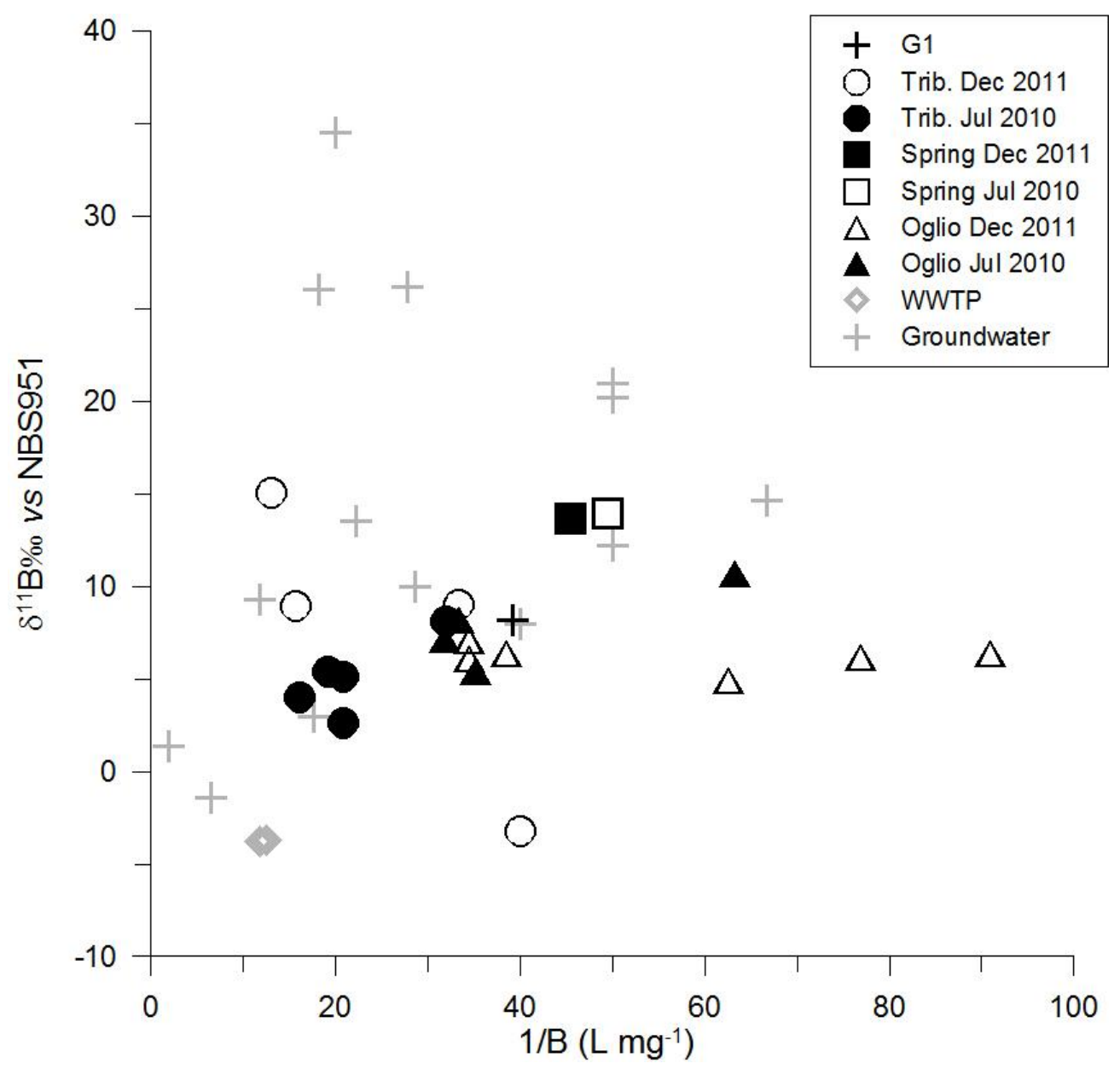




\section{Conflict of interest}

This paper reports the results of a research project co-funded by the National Research Council (CNR-IGG) and Lombardy Region, Department of Agriculture. The Oglio River Consortium and the Regional Agency for the Environmental Protection of Lombardy (ARPA Lombardia) provided flow and some chemical data, respectively. One of the authors (E. Racchetti) was supported by the Lombardy Foundation for the Environment (FLA).

Authors are not aware of any actual or potential conflict of interest including any financial, personal or other relationships with other people or organizations within three years of beginning the submitted work that could inappropriately influence, or be perceived to influence, their work. 